Transactions of the American Fisheries Society 128:414-435, 1999

(C) Copyright by the American Fisheries Society 1999

\title{
Field Test of Two Energetic Models for Yellow Perch
}

\author{
JEFFREY S. SCHAEFFER*1 \\ Department of Biology, University of Tampa, \\ 401 West Kennedy Boulevard, Tampa, Florida 33606, USA \\ RoBert C. HAAS \\ Michigan Department of Natural Resources, \\ 33135 South River Road, Mount Clemens, Michigan 48045, USA \\ James S. Diana \\ School of Natural Resources and Environment, University of Michigan, \\ Ann Arbor, Michigan 48109-1115, USA \\ JAMES E. BRECK \\ Institute for Fisheries Research, University of Michigan, \\ 1109 North University, Ann Arbor, Michigan 48109-1084, USA
}

\begin{abstract}
Field data from a population of yellow perch Perca flavescens in Saginaw Bay, Lake Huron, were used to evaluate the ability of two energetic models to predict consumption by yellow perch. Field estimates of daily ration for age-1-4 fish during May through October 1987 and 1988 were compared with independent predictions made by the Wisconsin energetic model and an energetic model developed by Karås and Thoresson. Predictions of daily ration using the Wisconsin model were lower than daily rations estimated from field data for all ages, primarily due to poor model-field agreement at temperatures above $22^{\circ} \mathrm{C}$. This caused estimates of cumulative consumption from the Wisconsin model to be $25-50 \%$ lower than field estimates. Predictions of daily ration by the Karås-Thoresson model agreed with field estimates over a temperature range of 10 $26^{\circ} \mathrm{C}$ for age-1-3 yellow perch but not for older fish. Despite improvement, model predictions of cumulative consumption were $2-35 \%$ lower than field estimates. Although these tests of predicted and estimated rations may provide insight into which model produced more accurate results, it must be emphasized that field measures of daily ration are also estimates and may be in error, particularly at temperatures above $22^{\circ} \mathrm{C}$ where gastric evacuation rates were estimated. The KaråsThoresson modification of the Wisconsin energetic model produced better fits to field ration data and is recommended for model applications.
\end{abstract}

The ability to estimate daily ration of wild fish is of critical importance to fisheries scientists attempting to understand growth or the impact of predatory fishes on their prey. However, daily ration estimates from field data are infrequent, highly variable, and often lack confidence limits (Adams and Breck 1990). Daily ration estimates can be influenced by factors such as predator size, prey size, prey type, amount eaten during a given feeding bout, water temperature, activity, rate of gastric or gut evacuation, and prior feeding history (Mann 1978; Windell 1978). These biases are difficult to evaluate outside of the laboratory (Mann 1978; Adams and Breck 1990). Furthermore, field

\footnotetext{
* Corresponding author: Jeff_schaeffer@usgs.gov

${ }^{1}$ Present address: U.S. Geological Survey, Great Lakes Science Center, 1451 Green Road, Ann Arbor, Michigan 48105, USA.

Received July 21, 1997; accepted August 4, 1998
}

estimates of daily ration are labor intensive, computationally demanding (Boisclair and Leggett 1988), and subject to sampling bias (Hayward et al. 1989). One attempt to overcome these problems has been the development of energetic models, which predict consumption using growth, temperature, and metabolic data (Kitchell et al. 1974, 1977).

Although energetic models appear to be powerful tools, confirmation of model predictions using field tests has been rare, and results have been inconsistent among taxonomic groups. Rice and Cochran (1984) found close agreement between observed and predicted consumption of largemouth bass Micropterus salmoides, and Beauchamp et al. (1989) found that an energetic model accurately predicted growth and consumption by three populations of sockeye salmon Onchorhynchus nerka. Using an energetic model, Hayward and Margraf (1987) predicted that slow growth of 
yellow perch Perca flavescens in Lake Erie's western basin was the result of low daily ration. Model predictions appeared to be confirmed by field estimates; however, their results have been contested (Boisclair and Leggett 1989a; Boisclair and Leggett 1990; Hayward 1990). An energetic model for sauger Stizostedion canadense accurately predicted consumption during summer but not during winter (Minton and McLean 1982). Poor fits between model predictions and field estimates of growth and consumption have been observed for northern pike Esox lucius, muskellunge Esox masquinongy, and their hybrids (Wahl and Stein 1991). Wahl and Stein (1991) questioned whether laboratoryderived physiological parameters were appropriate for wild, free-ranging fish. Additionally, among population differences in activity patterns may be important (Boisclair and Leggett 1989b). More recently, use of the models has been questioned because of possibly complex relationships between growth and consumption (Boisclair and Leggett 1990; Hayward 1990; Boisclair and Leggett 1991; Hewett et al. 1991).

The purpose of this study was to evaluate the ability of two energetic models (Hewett and Johnson 1992; Karås and Thoresson 1992) to accurately predict food consumption of age-1-4 yellow perch collected from inner Saginaw Bay, Lake Huron. Model predictions of daily ration and cumulative consumption were compared with field estimates obtained for the yellow perch population in inner Saginaw Bay.

\section{Methods}

Study area.-Saginaw Bay is a large, shallow embayment of Lake Huron. The inner bay is large (about $1,500 \mathrm{~km}^{2}$ ), shallow (mean depth $=4.5 \mathrm{~m}$ ) and moderately eutrophic with summer temperatures exceeding $25^{\circ} \mathrm{C}$ (Keller et al. 1987). The large surface: volume ratio of the inner bay results in frequent wind mixing of the water column, and isothermal conditions are common. This study examined fish collected from Wildfowl Bay, a shallow sub-bay on the east shore of the inner bay. Water quality and thermal conditions there showed only slight differences from other areas within the inner bay (Haas and Schaeffer 1992).

Empirical data.-All sampling was conducted from the Michigan Department of Natural Resources (MDNR) research vessel Channel Cat. Diel collections of yellow perch were made once each month during May through October 19871988 from a fixed station in Wildfowl Bay. Diel samples consisted of serial trawls of 10-min du-

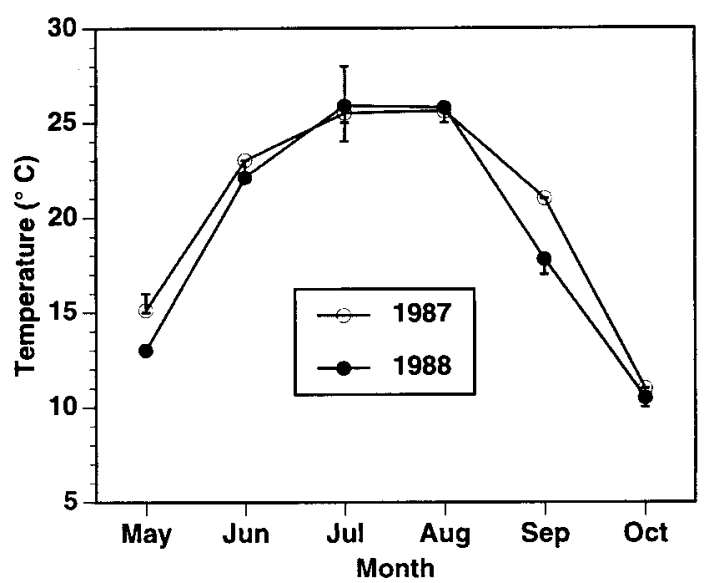

FIgURE 1.-Mean water temperatures $\left({ }^{\circ} \mathrm{C}\right)$ during May-October at the Wildfowl Bay diel station, Saginaw Bay, Lake Huron. Error bars represent temperature ranges encountered during a particular diel sample. Error bars smaller than symbols are not visible.

ration every $3 \mathrm{~h}$ for $24 \mathrm{~h}$ using an otter trawl with a 10.66-m headrope. The first sample was always taken about 1800 hours. During May and June 1987, eight serial trawls were performed during each survey, with the final sample being taken at 1500 hours. After June 1987, a ninth serial trawl collection at 1800 hours was added to the design. Temperature $\left({ }^{\circ} \mathrm{C}\right)$ was recorded concurrently with each trawl collection. Water temperatures ranged from $10^{\circ} \mathrm{C}$ to $26^{\circ} \mathrm{C}$ during the growing season and never varied more than $\pm 3^{\circ} \mathrm{C}$ during a diel sample (Figure 1).

Up to 52 adult and 10 yearling $(<100 \mathrm{~mm}$ total length) yellow perch were randomly sampled from each trawl collection. These sample sizes were chosen so that at least 10 yellow perch from each age-class were collected from each serial trawl. Sampled fish were stunned on ice for several minutes, frozen with liquid nitrogen, and held in a plastic cooler. Fish were kept frozen at $-25^{\circ} \mathrm{C}$ until processing.

Laboratory methods.-Yellow perch were thawed in the laboratory, measured $(\mathrm{mm})$, weighed $(0.01 \mathrm{~g})$, identified to sex, and scale samples were collected. Stomach contents of each fish were excised, weighed $(0.01 \mathrm{~g})$, and preserved in ethanol; later they were counted and identified to the lowest possible taxon (usually family for invertebrates and species for fish). Randomly selected subsamples of individual yellow perch were dried for $48 \mathrm{~h}$ at $90^{\circ} \mathrm{C}$, then weighed $(0.0001 \mathrm{~g})$. Percent water was calculated as $100 \times$ (wet weight - dry weight)/wet weight. Scale sam- 
ples from yellow perch were pressed into acetate slides, and ages were determined.

Growth was measured as change in mean weight of each age-class estimated each month from the diel collections. Body energy density of yellow perch was estimated using the regression developed by Craig (1977), which predicted energy density of Eurasian perch Perca fluviatilis from somatic percent water data.

Food consumption.-Daily ration was estimated monthly for age-1-4 yellow perch during May through October 1987 and 1988. Median and quartile specific weights of stomach contents of each age-class from each serial trawl sample were entered into Elliott and Persson's (1978) equation, presented as

$$
\begin{gathered}
\sum C_{t}=\frac{R_{t}}{1-e^{-R t}}\left[\left(S_{1}-S_{0} e^{-R t}\right)+\left(S_{2}-S_{1} e^{-R t}\right)\right. \\
\left.+\cdots\left(S_{m}-S_{m-1} e^{-R t}\right)\right],
\end{gathered}
$$

where $C_{t}$ is daily food consumption (food $\left.[\mathrm{g}] \cdot \mathrm{fish}^{-1}[\mathrm{~g}] \cdot \mathrm{d}^{-1}\right), \quad R$ is instantaneous gastric evacuation rate, $t$ is time between samples (h), $S_{o}$ is median specific food weight of the initial sample $\left(\mathrm{g} \cdot \mathrm{g}^{-1}\right)$, and $S_{m}$ is median specific food weight of the final sample $\left(\mathrm{g} \cdot \mathrm{g}^{-1}\right)$. Medians and quartiles were used as inputs rather than means and variances because specific food weights were not normally distributed (Kolmogorov test, $D=0.277, P$ $<0.01)$. These values will henceforth be called field estimates.

The instantaneous gastric evacuation rate, $R$, is a temperature-dependent exponential function described by the following relationship:

$$
R=a e^{b T},
$$

where $T$ is temperature $\left({ }^{\circ} \mathrm{C}\right)$ and $a$ and $b$ are constants (Durbin et al. 1983). We used the relationship between $R$ and temperature developed by Persson (1979) for Eurasian perch, with $a=$ 0.0182 , and $b=0.14$. The gastric evacuation rate was assumed to vary only with temperature and to remain unaffected by fish size, food size, meal size, or feeding frequency, and gastric evacuation was assumed to begin immediately after food ingestion without an appreciable time lag (Durbin et al. 1983). Use of the Elliott and Persson algorithm requires that a final sample be taken $24 \mathrm{~h}$ after the initial sample. Before July 1987, when only eight serial trawls were performed, median food weights of the final sample were assumed to be identical to the median weight of the initial sample $\left(S_{m}=\right.$
$S_{o}$ ). After July 1987, this assumption was not needed because a ninth sample was collected $24 \mathrm{~h}$ after the first sample.

Cumulative consumption during May-October of each year was estimated for age-1-4 yellow perch from field data. Daily ration between sampling dates was estimated using linear interpolation between successive monthly estimates. $\mathrm{Cu}$ mulative consumption was estimated by linearly interpolating body masses and feeding rates between sampling dates, determining the product of mass and feeding rate for each day, and summing the products for each sampling period.

Energetic models.-Daily food consumption was also estimated using two energetic models: (1) a revised fish bioenergetics model (Hewett and Johnson 1992), which is an upgrade of an earlier model (Hewett and Johnson 1987), hereafter referred to as the Wisconsin model, and (2) an energetic model developed by Karås and Thoresson (1992) for Eurasian perch, hereafter referred to as the Karås-Thoresson model. Both models were derived from the energetic model for yellow perch and walleye Stizostedion vitreum by Kitchell et al. (1977), and take the form

$$
G=C-(M+U+F),
$$

where $G$ is specific growth rate $\left(\mathrm{g} \cdot \mathrm{g}^{-1} \cdot \mathrm{d}^{-1}\right), C$ is specific rate of food consumption $\left(\mathrm{g} \cdot \mathrm{g}^{-1} \cdot \mathrm{d}^{-1}\right), M$ is specific rate of metabolism (including resting, active, and specific dynamic action), and $F$ and $U$ represent specific rates of egestion and excretion, respectively. All units are calculated in terms of energy ( $\mathrm{J})$, but growth and consumption are expressed as biomass $(\mathrm{g})$, using seasonal values of energy density $\left(\mathrm{J} \cdot \mathrm{g}^{-1}\right)$. In both models, metabolic processes are described by temperature and massspecific functions. The Wisconsin model (Hewett and Johnson 1992) allows alternative equations for modeling consumption, respiration, and egestionexcretion. When using this model, we specified metabolic functions recommended by the authors.

In the Wisconsin model, slopes for temperature dependence of consumption (CQ) and respiration (RQ), temperature optimum $\left(T_{o}\right)$ and maximum $\left(T_{m}\right)$, and values for egestion and excretion $(F+$ $U)$ are constants (Table 1). In the Karås-Thoresson model, they are power functions of weight (Table 1), which decreases daily ration at temperatures below $18^{\circ} \mathrm{C}$ but increases consumption at higher temperatures (Karås and Thoresson 1992). Karås and Thoresson (1992) also proposed a nonfeeding restriction between sunset and sunrise that was not 
TABLE 1.-Parameter values used in the Kara ${ }^{\circ} \mathrm{s}-$ Thoresson energetic model for Eurasian perch (Karås and Thoresson 1992) and the Wisconsin energetic model for adult yellow perch (Kitchell et al. 1977, Hewett and Johnson 1992); $B$ is body mass ( $\mathrm{g}$.

\begin{tabular}{|c|c|c|c|}
\hline \multirow[b]{2}{*}{ Symbol } & \multirow[b]{2}{*}{ Parameter description } & \multicolumn{2}{|c|}{ Parameter value in } \\
\hline & & $\begin{array}{l}\text { Karås- } \\
\text { Thoresson } \\
\text { model }\end{array}$ & $\begin{array}{l}\text { Wisconsin } \\
\text { model }\end{array}$ \\
\hline \multicolumn{4}{|c|}{ Consumption $(C)$} \\
\hline$a_{1}$ & Intercept for $C_{\max }$ & 0.40 & 0.25 \\
\hline$b_{1}$ & Slope for $C_{\max }$ & -0.27 & -0.27 \\
\hline $\mathrm{T}_{o}$ & $\begin{array}{l}\text { Optimum temperature } \\
\left({ }^{\circ} \mathrm{C}\right)\end{array}$ & $28 B^{-0.43}$ & 29 \\
\hline$T_{m}$ & Maximum temperature $\left({ }^{\circ} \mathrm{C}\right)$ & $32 B^{-0.029}$ & 32 \\
\hline$Q$ & $\begin{array}{l}\text { Slope for temperature de- } \\
\text { pendence of consump- } \\
\text { tion }\end{array}$ & $2.8 B^{-0.07}$ & 2.3 \\
\hline \multicolumn{4}{|c|}{ Respiration $(R)$} \\
\hline$a_{2}$ & Intercept for $R_{\max }$ & 0.035 & 0.035 \\
\hline$b_{2}$ & Slope for $R_{\max }$ & -0.20 & -0.20 \\
\hline$T_{o}$ & $\begin{array}{l}\text { Optimum temperature } \\
\left({ }^{\circ} \mathrm{C}\right) \text { for standard respi- } \\
\text { ration }\end{array}$ & $32 B^{-.029}$ & 32 \\
\hline$T_{m}$ & $\begin{array}{l}\text { Maximum temperature } \\
\left({ }^{\circ} \mathrm{C}\right) \text { for standard respi- } \\
\text { ration }\end{array}$ & $35 B^{-0.013}$ & 35 \\
\hline$Q$ & $\begin{array}{l}\text { Slope for temperature de- } \\
\text { pendence of standard } \\
\text { respiration }\end{array}$ & $2.0 B^{0.07}$ & 2.1 \\
\hline$S$ & Specific dynamic action & 0.172 & 0.172 \\
\hline Act & Activity & 1.0 & 1.0 \\
\hline \multicolumn{4}{|c|}{ Egestion and excretion $(F+U)$} \\
\hline & $\begin{array}{l}\text { Proportion of consumed } \\
\text { food }\end{array}$ & $0.36 B^{0.07}$ & Equation $(2)^{\mathrm{a}}$ \\
\hline
\end{tabular}

included. The Karås-Thoresson model was implemented by modifying appropriate metabolic parameters in the Wisconsin model (Hewett and Johnson 1992). This was consistent with the manner in which Karås and Thoresson's (1992) model was implemented, and it facilitated direct comparison. Because all model inputs, calculations, and outputs were identical, the two models differed only in metabolic parameters (Table 1). Both models allowed us to examine effects of seasonal variation in yellow perch diet and energy density, which varied in Saginaw Bay.

Daily food consumption of age-1-4 yellow perch was predicted for each growing season from growth and temperature data using both energetic models. These values will henceforth be called model predictions $(\mathrm{P})$. The May through October period was divided into monthly intervals and a separate proportion of maximum consumption ( $\mathrm{P}$ value) was fitted to each interval using growth and temperature data. Consumption was estimated in a curve fitting exercise that used $\mathrm{P}$ as the sole independent variable, and possible values of consumption were constrained by the requirement that simulated size must agree with measured size on the dates of observation (Bartell et al. 1986). Each simulation generated a daily prediction of ration for each age-class, and summed daily predictions to calculate cumulative consumption for May through October. Prey availability was assumed to be constant within a simulation interval. No attempt was made to estimate growth from consumption and temperature data because use of energetic models for this purpose has been discouraged (Kitchell et al. 1977; Bartell et al. 1986; Hewett and Johnson 1992).

Model inputs.-Both energetic models required inputs for temperature, monthly weight change of yellow perch, energy densities of yellow perch and their prey, and proportional contribution of individual prey types to the total wet weight of the diet. Water temperatures were recorded during diel surveys, and temperature change between monthly samples was assumed to be linear. Behavioral thermoregulation by yellow perch inhabiting inner Saginaw Bay was unlikely because the water column was isothermal, and summer water temperatures throughout the inner bay during the study were almost uniform (Haas and Schaeffer 1992). Growth and energy densities of each age-class were estimated from field data. Energy densities of prey taxa were estimated from published research (See Table 2 for energy densities and sources). Energy densities of alewife and gizzard shad were varied seasonally, but energy densities of other prey types were assumed to remain constant. No data were available for trout-perch, so a value of 4,184 J/g was assumed (Hewett and Johnson 1992). Although yellow perch consumed 27 distinct prey types, prey were pooled into 11 categories representing taxa with similar energy densities. These were: chironomids (Insecta: Diptera), adult insects, zooplankton, mollusks, gizzard shad, alewife, yellow perch, trout-perch, rainbow smelt, cyprinids Notropis spp., and unidentified fish (Table 2). To estimate proportional contribution of each prey type to the total wet weight of the diet, counts of individual taxon were converted to wet weights using median dry weights for each taxon from Hayward and Margraf (1987) and percent water data (Cummins and Wuycheck 1971; Rottiers and Tucker 1982; Hewett and Johnson 1992).

One difficulty encountered in implementing the models was that a large proportion of the prey fish 
TABLE 2.-Energy densities of prey used as inputs to the energetic models.

\begin{tabular}{|c|c|c|}
\hline Taxon & $\begin{array}{l}\text { Energy density } \\
\text { (J/g wet weight) }\end{array}$ & Source \\
\hline Chironomid larvae & 3,138 & Cummins and Wuycheck (1971) \\
\hline Adult insects & 3,138 & Cummins and Wuycheck (1971) \\
\hline Zooplankton & 2,510 & Hewett and Johnson (1992) \\
\hline \multicolumn{3}{|l|}{ Alewife } \\
\hline Alosa pseudoharengus & $5,134-9,883$ & Flath and Diana (1985) \\
\hline \multicolumn{3}{|l|}{ Gizzard shad } \\
\hline Dorosoma cepedianum & $5,021-5,523$ & Pierce et al. (1980) \\
\hline \multicolumn{3}{|l|}{ Rainbow smelt } \\
\hline Osmerus mordax & 5,720 & Foltz and Norden $(1977)^{\mathrm{a}}$ \\
\hline \multicolumn{3}{|l|}{ Trout-perch } \\
\hline Percopsis omiscomayus & 4,184 & Assumed \\
\hline \multicolumn{3}{|l|}{ White perch } \\
\hline Morone americana ${ }^{\mathrm{b}}$ & 4,456 & Wissing (1974) \\
\hline \multicolumn{3}{|l|}{ Emerald shiner } \\
\hline Notropis atherinoides & 4,983 & Kelso (1972) \\
\hline \multicolumn{3}{|l|}{ Spottail shiner } \\
\hline Notropis hudsonius & 4,983 & c \\
\hline Yellow perch & 5,698 & Diana and Salz (1990) \\
\hline Unidentified fish & 4,983 & d \\
\hline
\end{tabular}

found in yellow perch stomachs could not be identified. In many other studies of piscivores, unidentified prey fish were excluded from analyses because all prey fish were assumed to digest at similar rates, which should not bias dietary proportions (Swenson and Smith 1973; Hartman and Margraf 1992). In this study, unidentified fish made up a significant proportion of the diet in most months when fish were consumed, and occasionally no prey fish species could be identified. We reasoned that most of the unidentified fish found in yellow perch stomachs were spottail shiner because this species exhibits a high degree of spatial overlap with yellow perch and is vulnerable to predation due to small size and lack of spines. Other prey fishes observed in stomachs possessed distinguishing features that facilitated identification even after considerable digestion. Spottail shiners were also abundant consistently in trawl samples at the diel station (Haas and Schaeffer 1992). Consequently, unidentified fish were retained as a dietary component within the energetics model, and were assumed to have an energy density of 4, $983 \mathrm{~J} / \mathrm{g}$ wet weight (Hewett and Johnson 1992). Kelso (1972) reported this value as the caloric density of emerald shiner which should be similar to that of spottail shiner.

Statistical methods.-Differences between male and female energy densities and daily ration estimates were tested using one-way analysis of variance (ANOVA) for individual sexes, ages, months, or years. The ANOVA assumptions were tested using the Shapiro-Wilk test (normality) and Bartlett's test (homogeneity of variance; SAS Institute 1987). Slopes and intercepts of model-field regressions were examined using Bonferroni joint confidence intervals (Neter et al. 1985). Differences among model-field regressions were tested using analysis of covariance (ANCOVA; SAS Institute 1987). Assumptions under ANCOVA were tested using the Shapiro-Wilk test and Bartlett's test (SAS Institute 1987). All statistical comparisons were performed using the Statistical Analysis System (SAS; SAS Institute 1987), with alpha set at 0.05 . Ninety-five percent confidence intervals were computed for means.

Relationships between energetic model predictions and field estimates were evaluated for each model by comparing regressions of model predictions versus field estimates. Ideally, both values should have agreed closely, and the regression would have had a slope of one, an intercept of zero, with an $r^{2}$ value close to one (Rice and Cochran 1984). Deviation was defined as the difference between a model prediction and a field estimate of daily ration for a particular age-class and date and represents the distance of an individual measurement from the 1:1 regression line. For all comparisons, differences were judged to be significant at $P<0.05$.Model-field agreement was also evaluated using Theil's (1961) decomposition of mean square error (MSE), presented as 


$$
\begin{aligned}
\mathrm{MSE} & =\frac{1}{n} \sum_{i=1}^{n}\left(P_{i}-A_{i}\right)^{2} \\
& =(\bar{P}-\bar{A})^{2}+\left(S_{p}-r S_{a}\right)^{2}+\left(1+r^{2}\right) S_{a}^{2},
\end{aligned}
$$

where $n$ is the number of paired observations, and $P_{i}$ and $A_{i}$ are model predictions and field estimates; $P, A, S_{p}$, and $S_{a}$ are the means and standard deviations of $P_{i}$ and $A_{i}$, respectively, and $r$ is their correlation coefficient. Decomposition of the MSE partitions the variance around the $1: 1$ regression line into three categories: $M, S$, and $R$. The mean component $(M)$ results from differences between the means of model predictions and field estimates, while $S$ represents the variance that results from deviation of the slope of the model-field leastsquares regression from a 1:1 line. The residual component $(R)$ results from random error. Dividing each estimate by MSE provides the proportion of MSE attributable to each component $(M, S$, and $R$ ). The ideal outcome is $M=0, S=0$, and $R=$ 1 , which indicates that errors in the model are nonsystematic.

Differences between model predictions and field estimates of cumulative consumption were evaluated by calculating percent error, presented as $100 \times($ model prediction - field estimate)/field estimate. Percent error in cumulative consumption was determined for each age-class during 1987 and 1988 (eight comparisons).

\section{Results \\ Field Estimates of Growth and Daily Ration}

Field data from trawl collections were adequate to directly estimate daily ration for age-1-4 yellow perch during 1987 and 1988, but sexes had to be pooled to maintain sample size. Sample sizes always exceeded 37 fish of each age per month, and about half the diel surveys provided more than 90 fish of each age (Table 3). Age-5 and older yellow perch were rare in this population, and their ration could not be estimated (Haas and Schaeffer 1992).

Seasonal growth of age-1-4 yellow perch varied little across years, and showed similar trends among ages and months. During both years the majority of growth for all age-classes occurred during May and June, and there was little somatic addition thereafter. During 1987, all age-classes experienced steady somatic addition during May through August; thereafter, little or no weight increase was observed for any age-class (Figure 2). In 1988, all age-classes experienced steady growth until July, after which age-2 and older fish stopped growing through September (Figure 2). Growth appeared to resume by October, because all ageclasses had regained or exceeded their July mean weights.

Energy densities increased with age, but varied during the growing season. Percent water was not significantly different between males and females, with the exception of age- 3 fish collected during 1988 (ANOVA, $P<0.05$, one of eight comparisons significant). The resulting difference in energy density between sexes would have been only $259 \mathrm{~J} / \mathrm{g}$ wet weight, so sexes were pooled within ages for estimates. Yellow perch from inner $\mathrm{Sa}$ ginaw Bay had estimated energy densities ranging from about 4,602 to 5,857 J/g (Figure 3). During 1987 , energy density of age-1 yellow perch increased until September, and energy density of age-2 and older fish peaked during July (Figure 3). During 1988, energy density of all age-classes peaked during August and declined thereafter (Figure 3 ).

The diet of age-1-4 yellow perch varied with age, but little across years, and only a few prey types made up most of the wet weight of diets (Table 3). Age-1-3 yellow perch consumed zooplankton during May or June, and fish were occasionally consumed during summer or autumn; however, chironomid larvae were the most important food item for these age-classes for nearly all months during both study years. Age-4 yellow perch relied on chironomid larvae during both study years, but fish constituted $30-40 \%$ of their diet during August and September of 1987, and they were almost completely piscivorous during October 1988. Prey fish were numerically rare in stomachs but predominated in the diets due to their large size compared with chironomid larvae (estimated median wet weight of a single prey fish $=0.4 \mathrm{~g}$; estimated median wet weight of a single chironomid larvae $=0.01 \mathrm{~g}$ ).

Field estimates of consumption did not vary significantly among ages or years (ANOVA, $F=$ $1.15, P>0.33)$, but there were seasonal changes. During May, field estimates of daily ration were low (about $0.02 \mathrm{~g} \cdot \mathrm{g}^{-1} \cdot \mathrm{d}^{-1}$ ) for all age-classes, but daily rations increased sharply by June (about $0.07-0.12 \mathrm{~g} \cdot \mathrm{g}^{-1} \cdot \mathrm{d}^{-1}$; Figures 4, 5). After June, daily ration declined steadily for age-1 yellow perch, but older age-classes appeared to maintain high feeding rates until July or August. Daily ration decreased for all age-classes during September of each year, and by October, low daily rations of about $0.01 \mathrm{~g} \cdot \mathrm{g}^{-1} \cdot \mathrm{d}^{-1}$ were observed for all age-classes.

Yellow perch consumed forage fish during late 
TABLE 3.-Food habits of age-1 through age-4 yellow perch from Wildfowl Bay, Saginaw Bay, Lake Huron. Values represent estimated percent contribution of individual prey categories to total wet weight of the diet; $N=$ number of fish sampled (in parentheses).

\begin{tabular}{|c|c|c|c|c|c|c|}
\hline $\begin{array}{l}\text { Prey type and } \\
\text { fish sample size }\end{array}$ & May & Jun & Jul & Aug & Sep & Oct \\
\hline \multicolumn{7}{|c|}{ Age 1, 1987} \\
\hline Chironomids & 83.0 & 85.2 & 93.7 & 81.9 & 82.4 & 94.6 \\
\hline Zooplankton & 17.0 & 11.3 & 0.2 & 0.4 & 0.9 & 4.2 \\
\hline Insects & 0 & 0.5 & 0.8 & 1.0 & 0 & 1.2 \\
\hline Unidentified fish & 0 & 3.0 & 5.3 & 16.7 & 16.7 & 0 \\
\hline$N$ & (61) & (59) & (76) & $(52)$ & (42) & (67) \\
\hline \multicolumn{7}{|c|}{ Age 1,1988} \\
\hline Chironomids & 92.9 & 57.7 & 92.5 & 81.2 & 96.1 & 23.0 \\
\hline Zooplankton & 6.5 & 25.7 & 6.0 & 0.2 & 0.9 & 3.4 \\
\hline Insects & 0.6 & 1.4 & 1.5 & 6.8 & 3.0 & 16.0 \\
\hline Unidentified fish & 0 & 15.2 & 0 & 11.8 & 0 & 57.6 \\
\hline$N$ & (84) & (86) & (74) & (128) & (126) & (110) \\
\hline \multicolumn{7}{|c|}{ Age 2, 1987} \\
\hline Chironomids & 97.4 & 93.0 & 96.0 & 85.7 & 90.1 & 98.9 \\
\hline Zooplankton & 2.4 & 3.4 & 0 & 0 & 0.3 & 1.0 \\
\hline Insects & 0.2 & 1.8 & 0.2 & 1.7 & 0.3 & 0.1 \\
\hline Unidentified fish & 0 & 1.8 & 3.8 & 12.6 & 9.3 & 0 \\
\hline$N$ & (132) & $(125)$ & (156) & (190) & $(249)$ & (161) \\
\hline \multicolumn{7}{|c|}{ Age 2,1988} \\
\hline Chironomids & 97.5 & 93.3 & 97.0 & 70.4 & 98.8 & 18.5 \\
\hline Zooplankton & 2.5 & 5.7 & 0.2 & 0 & 0.4 & 0.3 \\
\hline Insects & 0 & 1.0 & 2.8 & 9.5 & 0.8 & 7.0 \\
\hline Cyprinids & 0 & 0 & 0 & 10.0 & 0 & 0 \\
\hline Unidentified fish & 0 & 0 & 0 & 10.1 & 0 & 74.2 \\
\hline$N$ & (73) & (64) & (88) & $(84)$ & $(82)$ & (108) \\
\hline \multicolumn{7}{|c|}{ Age 3, 1987} \\
\hline Chironomids & 99.7 & 95.4 & 89.5 & 75.0 & 80.7 & 83.1 \\
\hline Zooplankton & 0.3 & 1.9 & 0 & 0 & 0.3 & 0.3 \\
\hline Insects & 0 & 1.3 & 0.1 & 1.4 & 0.5 & 0.1 \\
\hline Alewife & 0 & 0 & 1.6 & 1.6 & 0 & 0 \\
\hline Yellow perch & 0 & 0 & 3.3 & 0 & 0 & 4.8 \\
\hline Trout-perch & 0 & 0.7 & 0 & 0 & 4.6 & 0 \\
\hline Rainbow smelt & 0 & 0 & 0 & 0 & 4.6 & 0 \\
\hline Unidentified fish & 0 & 0.7 & 5.5 & 22.0 & 9.3 & 1.7 \\
\hline$N$ & (129) & $(142)$ & (165) & (204) & $(114)$ & (110) \\
\hline \multicolumn{7}{|c|}{ Age 3, 1988} \\
\hline Chironomids & 99.4 & 91.3 & 88.5 & 50.2 & 81.2 & 26.6 \\
\hline Zooplankton & 0.3 & 3.2 & 0.1 & 0.1 & 0.2 & 0.6 \\
\hline Insects & 0.3 & 3.0 & 8.2 & 3.8 & 1.8 & 8.0 \\
\hline Alewife & 0 & 0 & 0 & 0 & 2.8 & 0 \\
\hline Yellow perch & 0 & 0 & 2.5 & 5.3 & 0 & 0 \\
\hline Cyprinids & 0 & 0 & 0 & 2.5 & 0 & 0 \\
\hline Unidentified fish & 0 & 2.5 & 0.7 & 38.1 & 14.0 & 64.8 \\
\hline$N$ & (207) & $(227)$ & (243) & (182) & $(144)$ & (133) \\
\hline \multicolumn{7}{|c|}{ Age 4, 1987} \\
\hline Chironomids & 93.5 & 99.3 & 82.7 & 62.1 & 69.4 & 85.4 \\
\hline Zooplankton & 0 & 0.5 & 0 & 0 & 0.2 & 0.9 \\
\hline Insects & 0 & 0.2 & 0.3 & 0.7 & 0 & 0 \\
\hline Alewife & 0 & 0 & 3.8 & 22.3 & 0 & 0 \\
\hline Yellow perch & 0 & 0 & 0 & 0 & 30.4 & 0 \\
\hline Cyprinids & 4.8 & 0 & 0 & 0 & 0 & 0 \\
\hline Rainbow smelt & 1.7 & 0 & 13.2 & 14.9 & 0 & 13.7 \\
\hline$N$ & (92) & (89) & (61) & (51) & (53) & (49) \\
\hline
\end{tabular}


TABLE 3.-Continued.

\begin{tabular}{lcccccc}
\hline $\begin{array}{l}\text { Prey type and } \\
\text { fish sample size }\end{array}$ & May & Jun & Jul & Aug & Sep & Oct \\
\hline Chironomids & 97.7 & 96.0 & 95.6 & 33.0 & 98.8 & 5.9 \\
Zooplankton & 0 & 0.9 & 0 & 0 & 0.3 & 0 \\
Insects & 0.6 & 1.3 & 2.9 & 1.6 & 0.9 & 0.1 \\
Alewife & 0 & 1.8 & 0 & 0 & 0 & 0 \\
Yellow perch & 0 & 0 & 0 & 0 & 0 & 24.2 \\
Cyprinids & 0 & 0 & 0 & 0 & 0 & 11.6 \\
Trout-perch & 0 & 0 & 0 & 7.3 & 0 & 0 \\
Rainbow smelt & 1.7 & 0 & 1.5 & 58.1 & 0 & 58.2 \\
$N$ & $(122)$ & $(83)$ & $(86)$ & $(61)$ & $(37)$ & $(54)$ \\
\hline
\end{tabular}

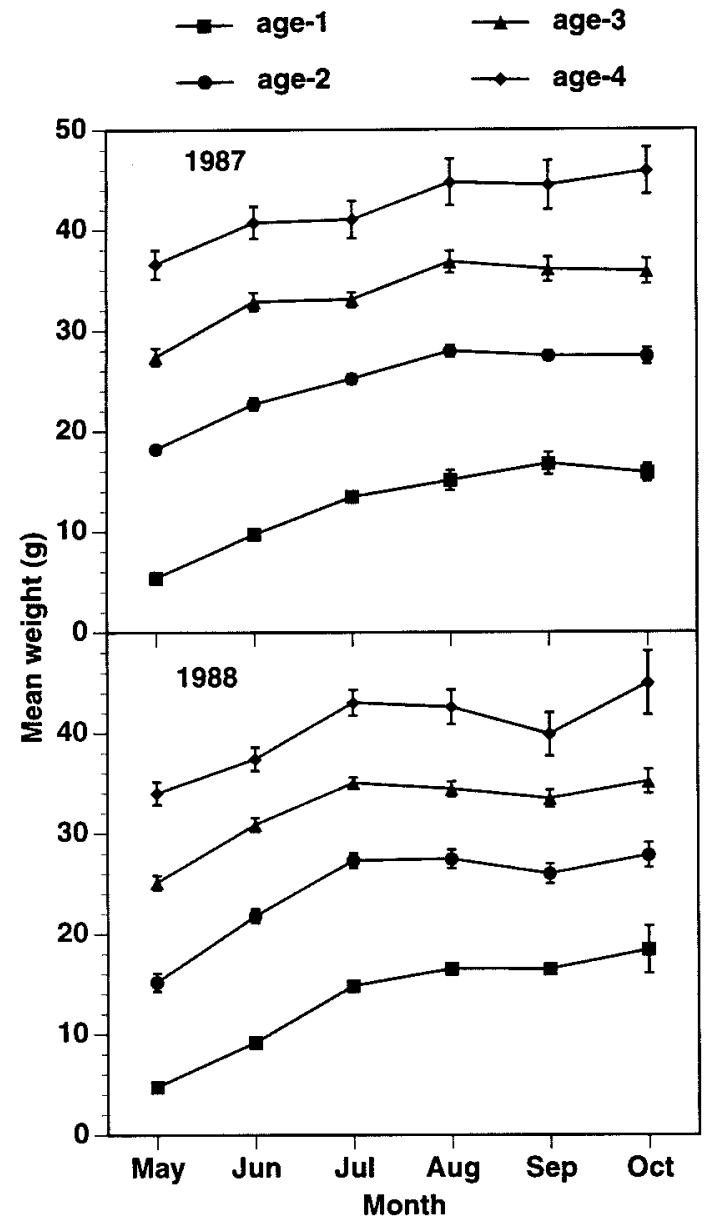

FIGURE 2.-Seasonal change in mean weight $(\mathrm{g})$ of age 1-4 yellow perch collected with bottom trawls during 1987 and 1988 from the Wildfowl Bay diel station in Saginaw Bay, Lake Huron. Error bars represent 95\% confidence intervals. Error bars smaller than symbols are not visible. summer or autumn, but piscivory did not increase daily ration above summer levels. Because sampling was performed only once each month, shortterm increases in daily ration due to pulses of forage fish recruitment may have gone undetected. However, piscivory did not improve growth because there was little or no weight increase for any age-class after July of each year, with the exception of age-4 yellow perch during September-October 1988. The diet of these individuals consisted almost entirely of fish during September and October, and they gained weight, but daily ration appeared to be low on both sampling dates.

\section{Model Predictions of Daily Ration}

Predictions of consumption by both models did not follow field estimates closely (Figures 4-7). For the Wisconsin model, predictions of daily ration were generally lower than field estimates during both years (Figures 4, 5) This was particularly evident during June, July, and August, when model predictions of daily ration for age-2-4 yellow perch were $30-50 \%$ lower than field estimates, and differences exceeded even quartile estimates of daily ration (Figures 4, 5). Model predictions tended to be closer to field estimates during spring and autumn for all age-classes during both years (Figures 4,5$)$.

Predictions by the Karås-Thoresson model followed field estimates more closely than Wisconsin model predictions. As with the Wisconsin model, Karås-Thoresson predictions of daily ration were often lower than field estimates during summer, with closer agreement during autumn (Figures 6, 7). Agreement during spring differed among years. In 1987, model-field agreement was close, but during 1988, the Karås-Thoresson model predicted daily rations that were much higher than field estimates (Figures 6, 7).

Predictions of daily ration differed between en- 


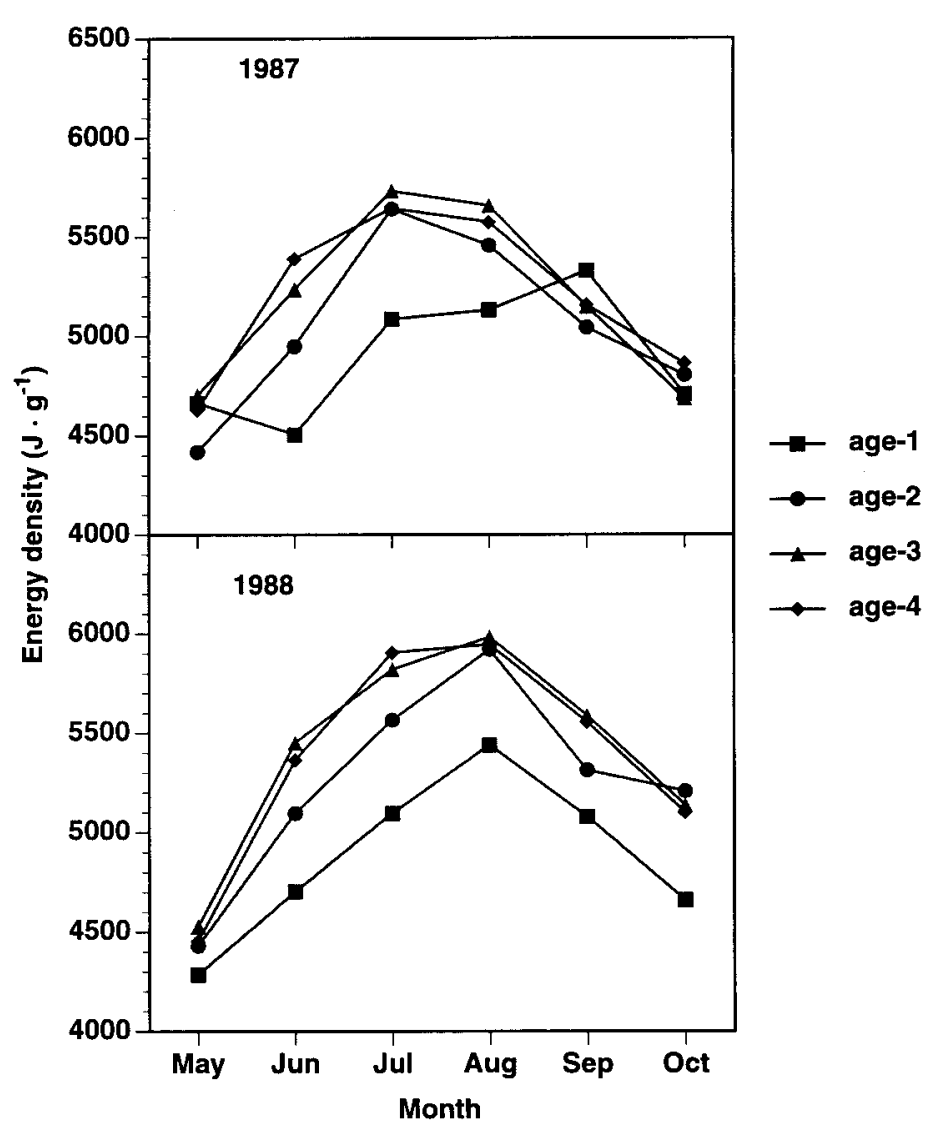

Figure 3.- Seasonal change in energy density $\left(\mathrm{J} \cdot \mathrm{g}^{-1}\right)$ of age 1-4 yellow perch collected with bottom trawls during 1987 and 1988 from Wildfowl Bay diel station in Saginaw Bay, Lake Huron, estimated from somatic percent water data and Craig (1977).

ergetic models. During both years, predicted daily rations made by the Karås-Thoresson model for age- 1 and age-2 fish were usually $0.01-0.02$ $\mathrm{g} \cdot \mathrm{g}^{-1} \cdot \mathrm{d}^{-1}$ greater than those predicted using the Wisconsin model. For age- 3 and age-4 yellow perch, model predictions by the Wisconsin and Karås-Thoresson models were similar, probably because power functions in the Karås-Thoresson model approached constants used in the Wisconsin model asymptotically as fish increased in size.

\section{Model Predictions Compared with Field Estimates}

Agreement between model predictions and field estimates, evaluated through least-squares regressions of model predictions on field estimates of daily ration, was not significantly different among years for slopes or intercepts of either regression. Consequently, data from 1987 and 1988 were pooled.
Linear models adequately defined both modelfield regressions; for the Wisconsin model

$$
Y_{1}=0.0093+0.586 \times X_{1} \quad\left(r^{2}=0.724\right),
$$

and for the Karås-Thoresson model

$$
Y_{2}=-0.0046+0.996 \times X_{1} \quad\left(r^{2}=0.744\right),
$$

$\left(r^{2}=0.744\right)$; where $X_{1}$ represents field estimates of daily ration $\left(\mathrm{g} \cdot \mathrm{g}^{-1} \cdot \mathrm{d}^{-1}\right), Y_{1}$ represents predictions from the Wisconsin model, and $Y_{2}$ represents predictions from the Karås-Thoresson model. Variances of the two regressions were not significantly different (Bartlett's test) and there were no serious violations of the assumption of normality (ShapiroWilk test), so ANCOVA was used to evaluate differences between model-field regressions.

Slopes and intercepts of the two regressions were significantly different (ANCOVA), and age or size effects were present in both model-field 


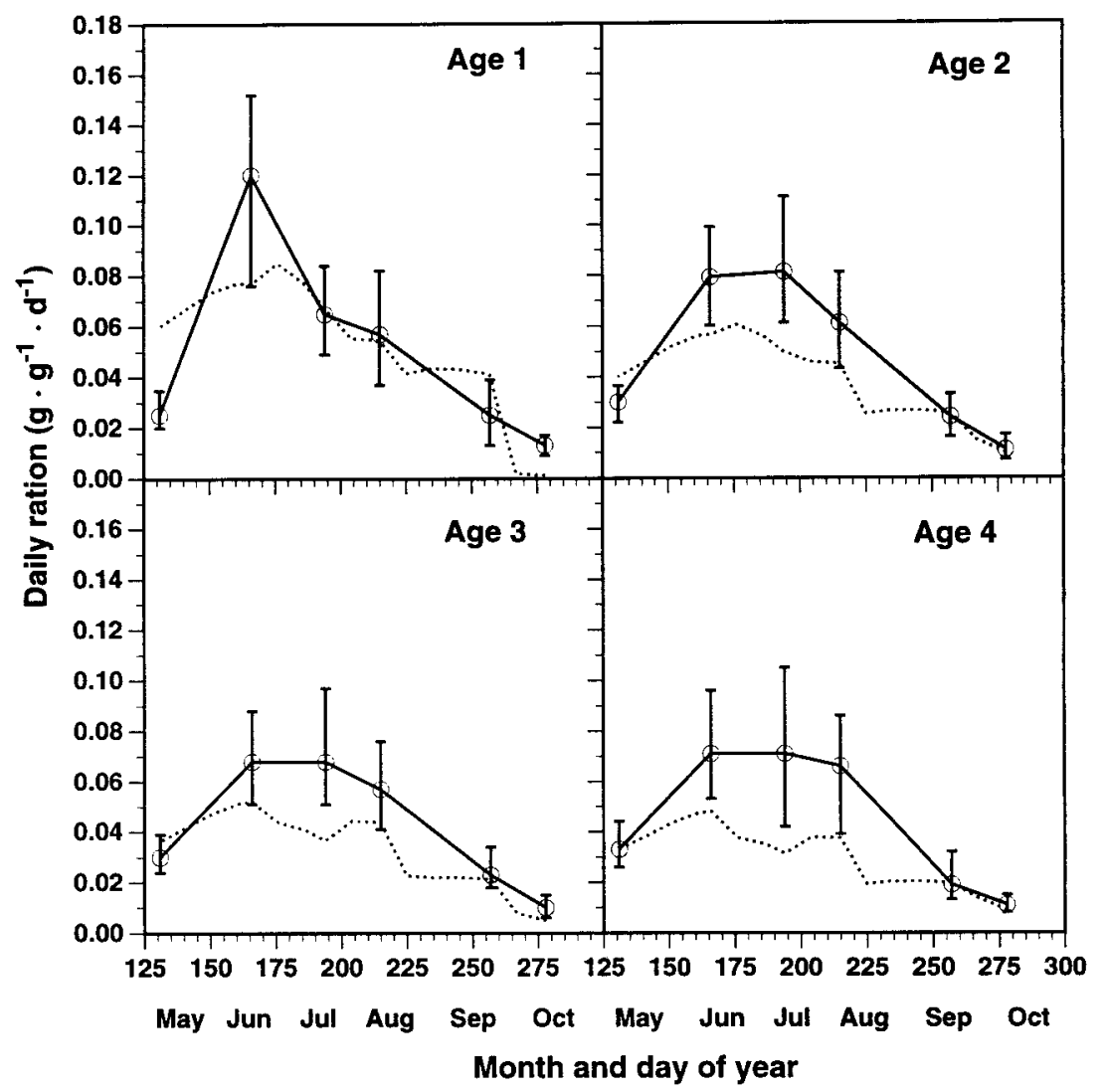

FIGURE 4.-Food consumption $\left(\mathrm{g} \cdot \mathrm{g}^{-1} \cdot \mathrm{d}^{-1}\right)$ on a wet weight basis of age 1-4 yellow perch during 1987 from Wildfowl Bay, estimated from median field estimates of daily ration (open circles), and the Wisconsin energetic model (dotted lines). Error bars represent quartiles (25th and 75th percentiles) of field estimates.

regressions. For the Wisconsin model, slopes of the model-field regression did not vary with age, but intercepts differed significantly (ANCOVA). For the Karås-Thoresson model, both slopes and intercepts varied significantly with age. Consequently, both model-field regressions were examined separately to evaluate differences among individual age-classes.

As field estimates of daily ration increased, the Wisconsin model predictions were increasingly lower than field estimates. Joint tests of the hypothesis that model-field regressions of individual age-classes had a slope of 1 and intercept of 0 were rejected (age-1-4, four comparisons, $P<$ 0.05 ). Slope estimates ranged from 0.65 (age-2) to 0.44 (age-4), and the trend toward underestimation of daily ration by the energetic model generally increased with age (Figure 8). Some Wisconsin model predictions were $30-50 \%$ lower than comparable field estimates, particularly for age-2-4 yellow perch.
Karås-Thoresson model predictions showed better agreement with field estimates for age-1-3 yellow perch, but not for age-4 fish (Figure 9). Model-field regressions for ages 1 through 3 had slopes and intercepts not significantly different from 1 and 0 , respectively (joint test, $P>0.05$, three comparisons), while age-4 fish had significant deviations (joint test, $P<0.05$, two comparisons). As with the Wisconsin model, Karås-Thoresson model predictions for age4 yellow perch were lower than field estimates, but slope estimates were somewhat higher than those obtained for age-4 fish using the Wisconsin model (Figure 9). For age-4 yellow perch some KaråsThoresson model predictions were about $30 \%$ lower than field estimates.

Theil's (1961) decomposition of MSE suggested that random error was the greatest source of disagreement between model predictions and field estimates for both models, but some systematic error was present. In the Wisconsin model most variation from the 1:1 line was due to random error, 


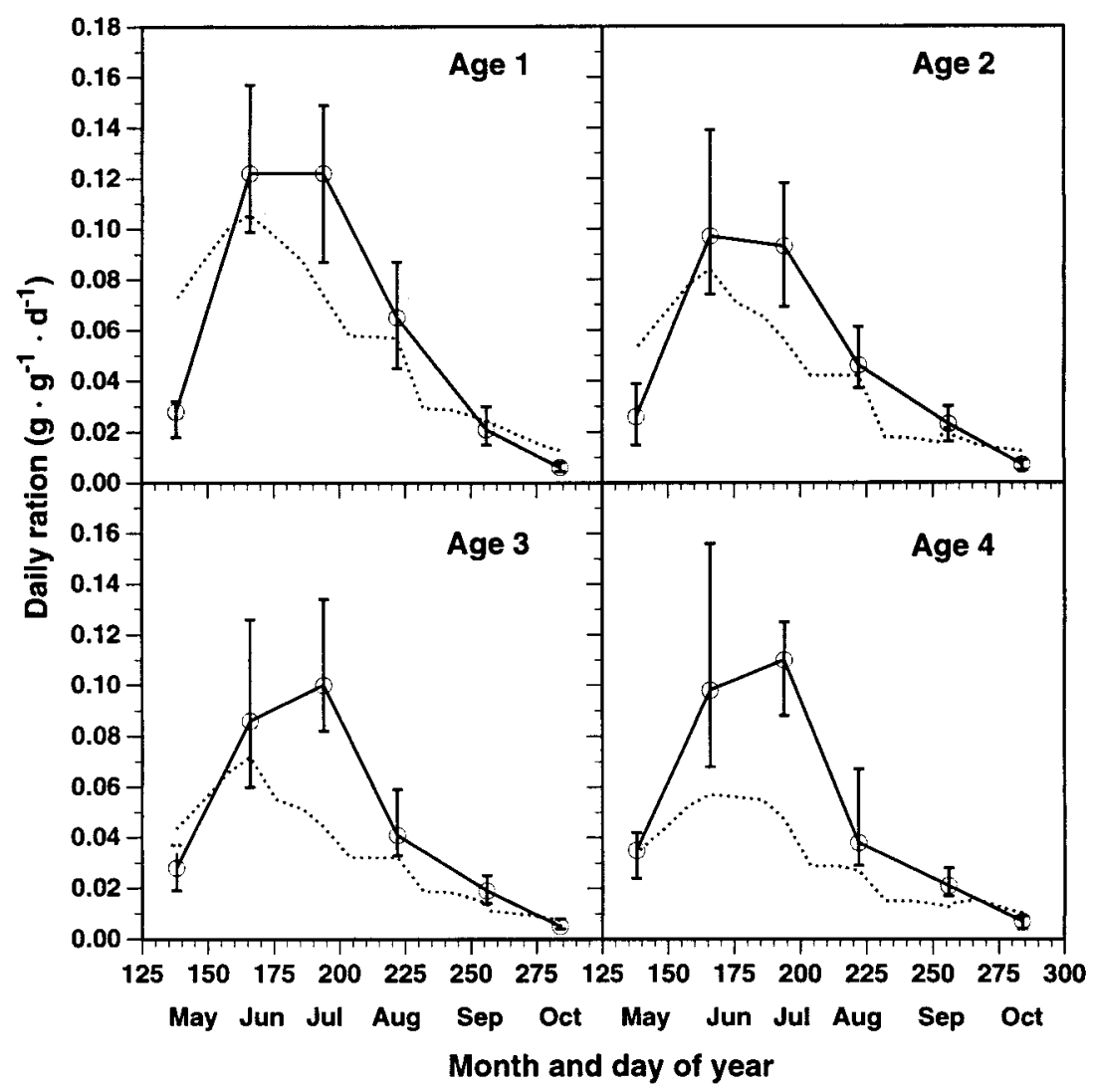

Figure 5.-Food consumption $\left(\mathrm{g} \cdot \mathrm{g}^{-1} \cdot \mathrm{d}^{-1}\right)$ on a wet weight basis of age 1-4 yellow perch during 1988 from Wildfowl Bay, estimated from median field estimates of daily ration (open circles), and the Wisconsin energetic model (dotted lines). Notation is the same as in Figure 4.

but systematic error increased from 0.02 for age1 fish to about 0.23 for age-4 fish (Table 4). With the Karås-Thoresson model, the proportion of variance due to systematic errors was smaller, but increased to about 0.12 for age-4 fish (Table 4).

Deviation (model prediction minus field estimate) was highest for both models when field estimates of daily ration were high, and high daily rations occurred at temperatures above $22^{\circ} \mathrm{C}$. Within the $10-22^{\circ} \mathrm{C}$ range, differences between predicted and observed values often fell within a range of $\pm 0.02 \mathrm{~g} \cdot \mathrm{g}^{-1} \cdot \mathrm{d}^{-1}$ for both model-field comparisons, but at higher temperatures we observed differences as large as 0.05-0.06 $\mathrm{g} \cdot \mathrm{g}^{-1} \cdot \mathrm{d}^{-1}$ for the models (Figures 10,11 ). Leastsquares simple linear regression of deviation versus temperature $\left({ }^{\circ} \mathrm{C}\right)$ indicated that temperature effects were present in the Wisconsin model, but not the Karås-Thoresson model. For the Wisconsin model, differences between model predictions and field estimates increased with temperature for age-
1-4 fish (Figure 10). For the Karås-Thoresson model, there was no significant relationship between deviation versus temperature (Figure 11). Although age and temperature affected agreement between model predictions and field estimates for both models, there was no interaction between temperature and age ( $F$-test).

Because temperature effects were quite large at temperatures exceeding $22^{\circ} \mathrm{C}$, deviation was reevaluated using data only from samples taken in the $10-22^{\circ} \mathrm{C}$ range. Removal of observations taken at temperatures greater than $22^{\circ} \mathrm{C}$ improved agreement between both model predictions and field estimates. For the Wisconsin model, there were no violations of ANCOVA assumptions with the reduced data set and no significant differences in model-field agreement between years, so the data were again pooled to examine age effects. Slopes of model-field regressions for individual ages were not significantly different, but intercepts were significantly different, suggesting that age effects 


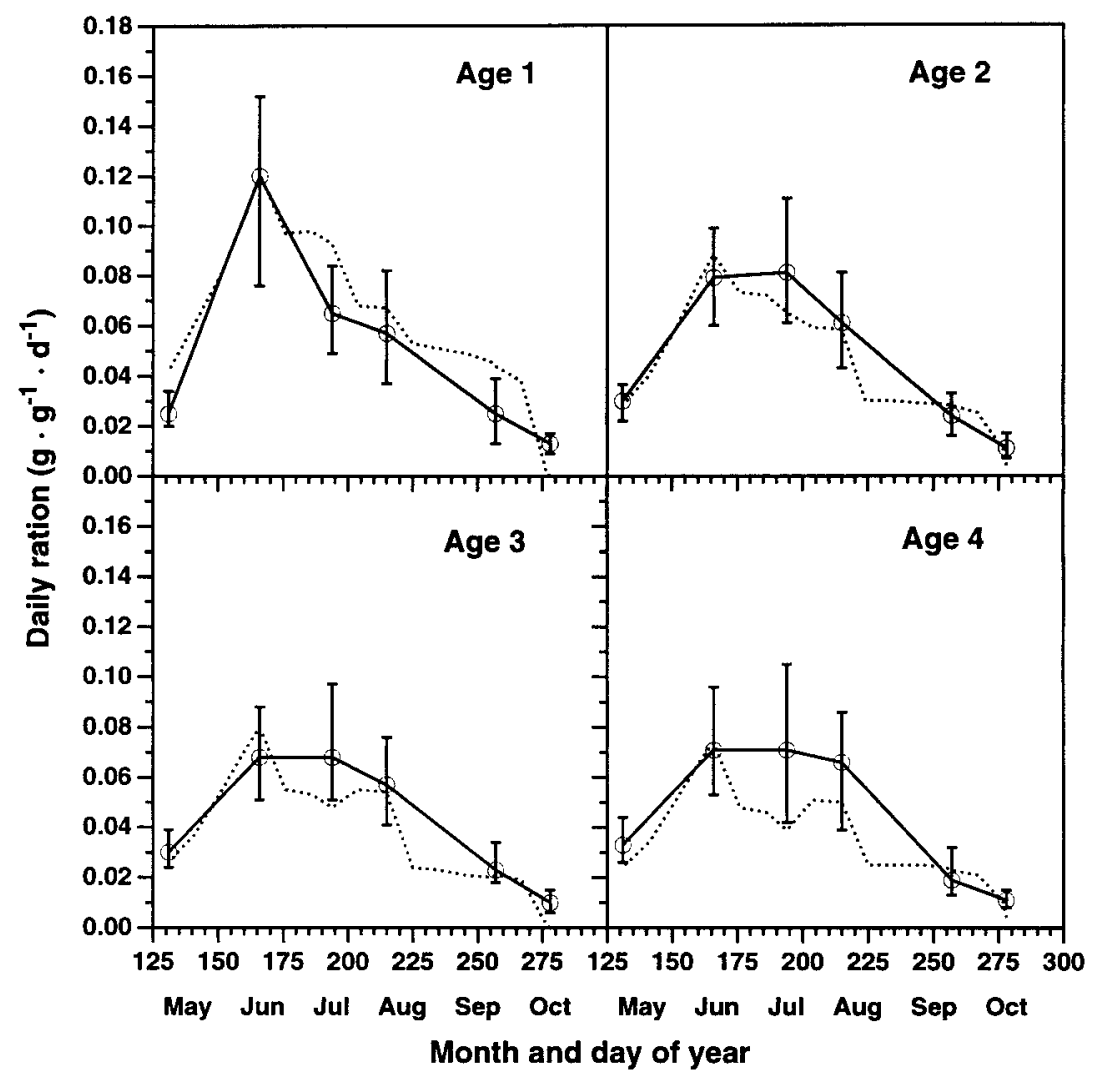

FIGURE 6.-Food consumption $\left(\mathrm{g} \cdot \mathrm{g}^{-1} \cdot \mathrm{d}^{-1}\right)$ on a wet weight basis of age 1-4 yellow perch during 1987 from Wildfowl Bay, estimated from median field estimates of daily ration (open circles), and the Karås-Thoresson energetic model (dotted lines). Notation is the same as in Figure 4.

remained. Over the range of 10 to $22^{\circ} \mathrm{C}$, regressions of model-field estimates for age-1-3 fish exhibited a slope of one and intercept of zero (joint test: $P>0.05$, three comparisons). However, Wisconsin model predictions were significantly lower than field estimates for age-4 fish $(P<0.05)$. Decomposition of MSE suggested that random effects were again the most important source of error in the Wisconsin model over the restricted temperature range; very little systematic error remained for age-1-3 fish, and systematic errors were reduced for age-4 fish (Table 4).

The Karås-Thoresson model also had improved agreement with field estimates within the range of $10-22^{\circ} \mathrm{C}$. There were no significant differences in model-field agreement between years or ages. Consequently all data were pooled. A significant linear regression described the relationship between model predictions and field estimates over $10-22^{\circ} \mathrm{C}$, with a slope of 1.09 and intercept of $-0.01(r=0.762)$.

Over the range of 10 to $22^{\circ} \mathrm{C}$, regression of mod- el-field estimates for the Karås-Thoresson model revealed a slope of 1 and intercept of 0 , indicating model-field agreement in this range of temperatures. Decomposition of MSE suggested that random effects were the only important source of error in the Karås-Thoresson model over the restricted temperature range (Table 4).

Estimates of cumulative consumption by the Wisconsin model during May-October were 16-45\% less than field estimates (Table 5), and were the result of the consistent tendency for Wisconsin model predictions to be lower than field estimates at high temperatures. Despite better agreement between model predictions and field observations, predictions by the Karås-Thoresson model using the full data were $2-35 \%$ lower than field estimates; however, agreement was better than that obtained by the Wisconsin model for all comparisons (Table 5).

\section{Discussion}

We evaluated the ability of the Wisconsin and Karås-Thoresson energetic models to predict field 


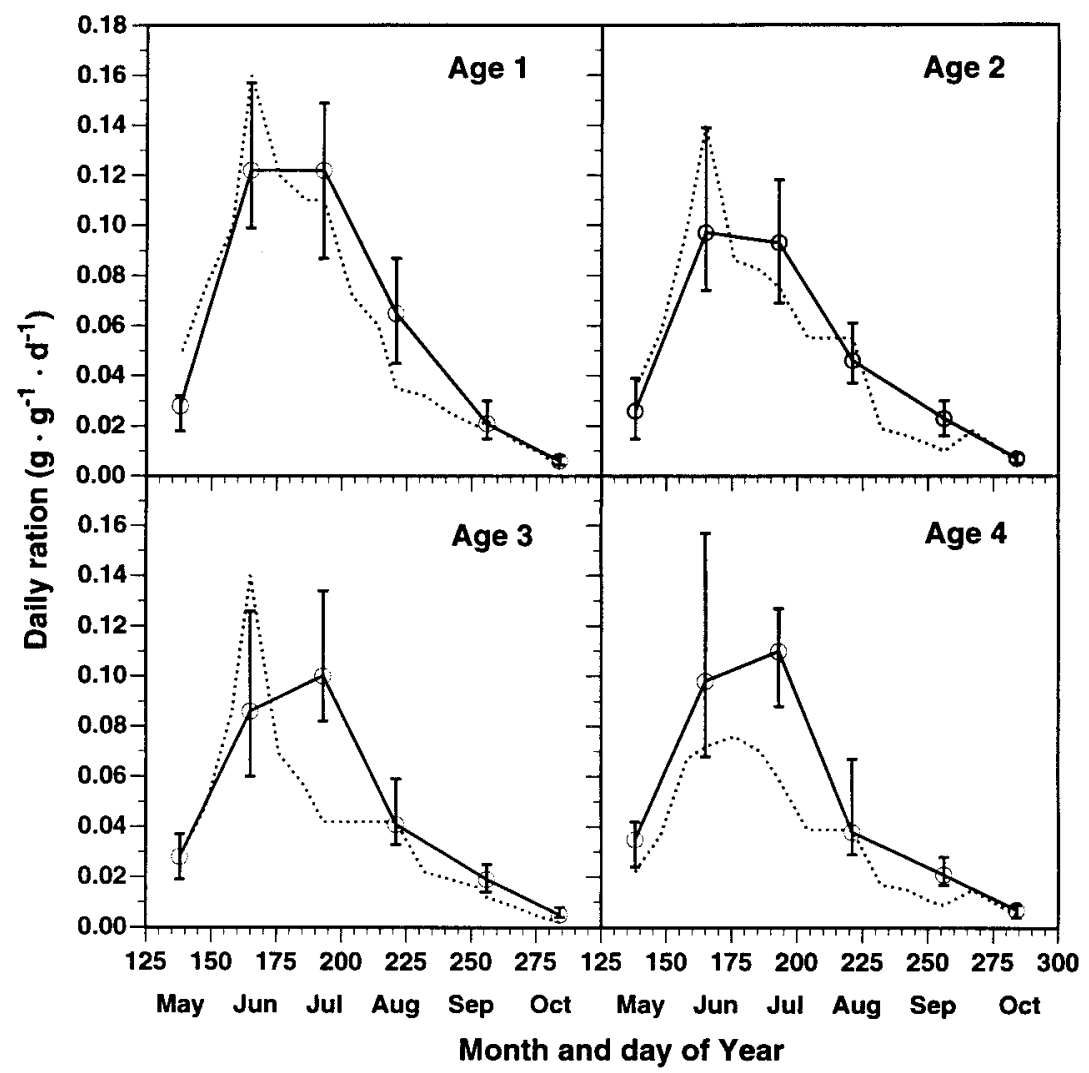

FIGURE 7.-Food consumption $\left(\mathrm{g} \cdot \mathrm{g}^{-1} \cdot \mathrm{d}^{-1}\right)$ on a wet weight basis of age 1-4 yellow perch during 1988 from Wildfowl Bay, estimated from median field estimates of daily ration (open circles), and the Karås-Thoresson energetic model (dotted lines). Notation as in Figure 4.

estimates of consumption for age-1-4 yellow perch collected during the May-October growing season from Saginaw Bay, Lake Huron. Over a temperature range of $10-26^{\circ} \mathrm{C}$, predictions of daily ration from the Wisconsin energetic model were consistently lower than field estimates. Agreement between model predictions and field estimates differed among age-classes and was influenced strongly by temperature. For the Karås-Thoresson model, agreement between model predictions and field estimates was good for age-1-3 fish, but not for age-4 yellow perch. Some age effects were present, but they were less important, and temperature did not significantly influence results.

Within a temperature range of $10-22^{\circ} \mathrm{C}$, modelfield agreement of the Wisconsin model improved. Wisconsin model predictions were not significantly different from field estimates for age-1-3 yellow perch, but were lower than field estimates for age-4 fish. The Karås-Thoresson model also performed well within a temperature range of 10 $22^{\circ} \mathrm{C}$. No age effects were present, and model pre- dictions of daily ration using pooled data were not significantly different than field estimates. Wisconsin model predictions for cumulative consumption of prey were 16-45\% lower than field estimates; Karås-Thoresson estimates were 2$35 \%$ lower than field estimates. For all comparisons, Karås-Thoresson predictions were closer to field estimates.

Efforts to corroborate energetics models for yellow perch have had mixed results. Mills and Forney (1981) reported close agreement between observed and predicted weights of age-0 yellow perch in Oneida Lake, New York, but did not perform statistical analysis. Hayward and Margraf (1987) suggested that field data corroborated Wisconsin model predictions that slow growth of yellow perch in the western basin of Lake Erie was the result of low consumption rates. However, their methods and conclusions have been debated strongly (Boisclair and Leggett 1989a, 1990; Hayward 1990). Karås and Thoresson (1992) suggested that their modification of the Wisconsin 


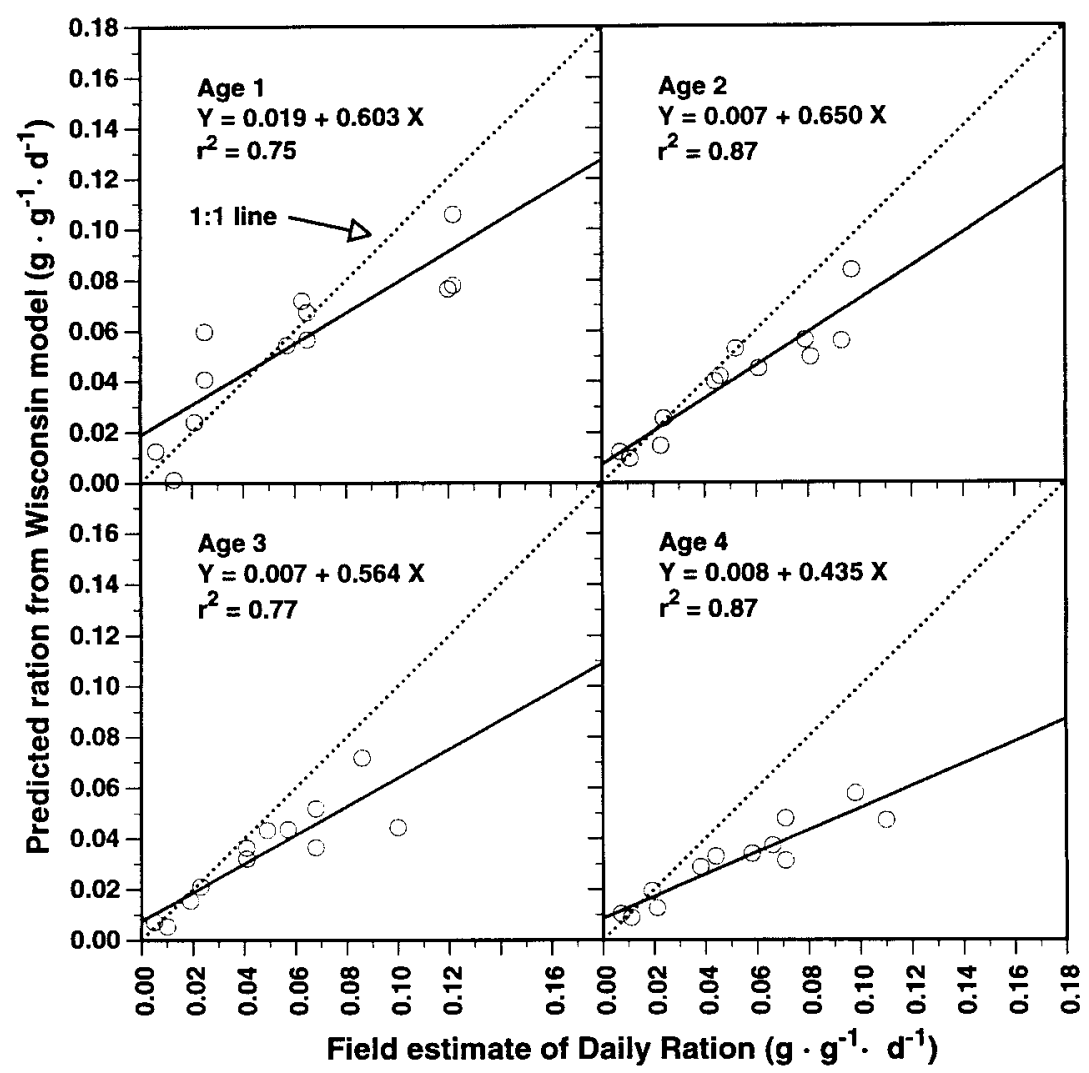

FIGURE 8.-Wisconsin energetic model predictions of daily ration versus median field estimates of daily ration for age 1-4 yellow perch collected from Wildfowl Bay. Data from 1987 and 1988 were pooled. If agreement were perfect (model predictions $=$ field estimates), all data points would fall on the dotted line.

model was corroborated because the model accurately predicted growth of age-0 Eurasian perch, but this suggestion was based solely on graphical evaluation of observed versus predicted seasonal growth. Efforts to corroborate the Wisconsin model for three age-classes of yellow perch in $12 \mathrm{Ca}$ nadian lakes failed (Boisclair and Leggett 1989b). Field estimates of cumulative consumption for the 12 populations of age- 1 yellow perch were almost identical to model predictions, but model predictions for age- 2 and age- 3 fish were $34 \%$ and $51 \%$ lower than field estimates, respectively. As with this study, Wisconsin model predictions tended to be lower than field estimates, and differences increased with age (Boisclair and Leggett 1989b). Boisclair and Leggett (1989b) suggested that variation in activity among populations was the primary cause of lack of agreement between model predictions and field estimates.

\section{Potential Errors in Model Parameters}

Errors in model parameters could have caused the lack of agreement between model predictions and field estimates. Complete laboratory data on consumption and growth of yellow perch were not available to Kitchell et al. (1977); consequently, a mixture of data for Eurasian perch, yellow perch, and other species was used to develop the original Wisconsin model (Kitchell et al. 1977; Karås and Thoresson 1992). Karås and Thoresson (1992) refit parameters to the Wisconsin model using consumption, respiration, and egestion-excretion data collected by Lessmark (1983) for captive 2-80 g Eurasian perch consuming a diet of mixed invertebrates over a temperature range of $4-28^{\circ} \mathrm{C}$.

Use of both energetic models assumed that laboratory derived metabolic parameters used in the models were applicable to wild fish, and that metabolic relationships for yellow perch were similar to those obtained for Eurasian perch. Although it is possible that the metabolic characteristics of wild fish could have been different from fish confined in a laboratory; to our knowledge, this assumption remains untested. The latter assumption appeared reasonable because Eurasian perch and 


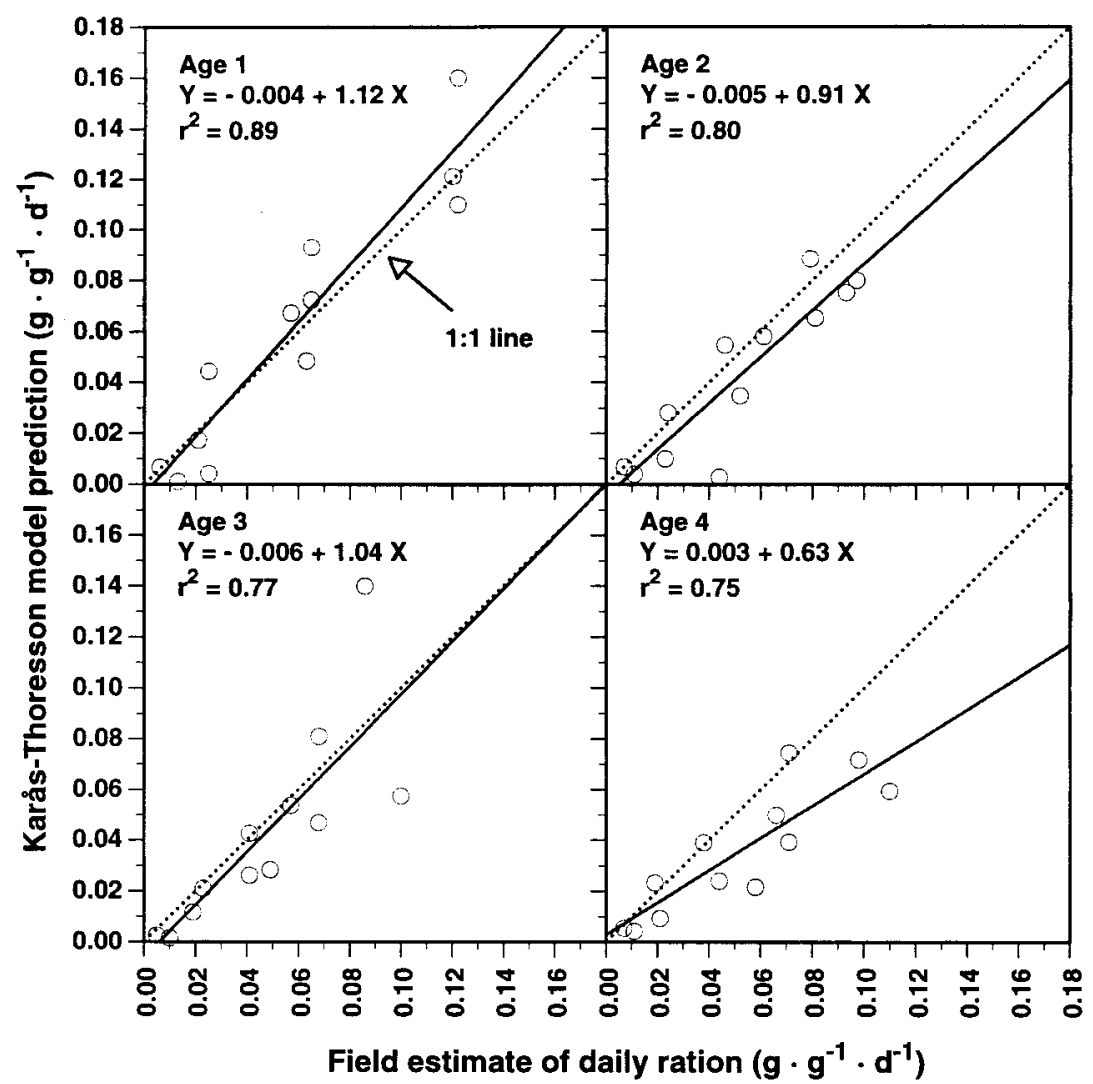

FigurE 9.- Kara ${ }^{\circ} \mathrm{s}-$ Thoresson energetic model predictions of daily ratio versus median field estimates of daily ration for age 1-4 yellow perch collected from Wildfowl Bay. Notation as in Figure 8.

yellow perch appear to be overwhelmingly equivalent biologically (Thorpe 1977a) and share similar thermal niches (Hokanson 1977).

Lack of agreement between model predictions and field estimates was consistent with Boisclair and Leggett's (1989b) hypothesis that activity costs can be a large and variable component of energy budgets. Decomposition of MSE suggested that in most cases greater systematic biases were present when observations at higher temperatures were included, and bias increased with age. If activity were a greater proportion of the yellow perch energy budget and positively correlated with temperature or age, both models would have probably underestimated metabolism, underestimated ration, and caused model predictions to be lower than field estimates of ration at high temperatures.

For both energetic models, we believe that activity bias was minimal, at least for temperatures of $10-22^{\circ} \mathrm{C}$, because most model predictions of daily ration were not significantly different from field estimates. This is likely due to the fact that the metabolic parameters for respiration used in both models were derived using laboratory aquaria that permitted some activity (Solomon and Brafield 1972). Possibly, activity may increase at high temperatures. In that case, variation in activity could have influenced model predictions and modelfield deviations at temperatures greater than $22^{\circ} \mathrm{C}$ (Boisclair and Leggett 1989b).

\section{Potential Errors in Model Inputs}

Five inputs were required to implement each energetic model: water temperature, growth, percent contribution of each prey type to the total wet weight of the diet, energy density of yellow perch, and prey energy density. Water temperatures were measured monthly in an isothermal environment that eliminated the possibility of temperature refuges or behavioral thermoregulation. We also made several assumptions about model inputs for predator and prey energy density, growth, and the proportional contribution of individual prey types to the total wet weight of the diet. 
TABLE 4.- Proportion of mean square error due to systematic (mean and slope) and random (residual) error for the relation between daily ration estimates from two bioenergetic models compared with field estimates of daily ration. The ideal outcome is mean $=0$, slope $=0$, and residual $=1$, which indicates that errors in the model are nonsystematic.

\begin{tabular}{|c|c|c|c|}
\hline Age & Mean & Slope & Residual \\
\hline \multicolumn{4}{|c|}{ Wisconsin model $\left(10-26^{\circ} \mathrm{C}\right)$} \\
\hline 1 & 0.006 & 0.014 & 0.980 \\
\hline 2 & 0.065 & 0.012 & 0.923 \\
\hline 3 & 0.098 & 0.022 & 0.880 \\
\hline 4 & 0.166 & 0.066 & 0.768 \\
\hline \multicolumn{4}{|c|}{ Karås-Thoresson model $\left(10-26^{\circ} \mathrm{C}\right)$} \\
\hline 1 & 0.004 & 0.063 & 0.933 \\
\hline 2 & 0.052 & 0.015 & 0.938 \\
\hline 3 & 0.012 & 0.100 & 0.888 \\
\hline 4 & 0.114 & 0.008 & 0.878 \\
\hline \multicolumn{4}{|c|}{ Wisconsin model $\left(10-22^{\circ} \mathrm{C}\right)$} \\
\hline 1 & 0.012 & 0.002 & 0.986 \\
\hline 2 & 0.001 & 0.001 & 0.998 \\
\hline 3 & 0.015 & 0.001 & 0.984 \\
\hline 4 & 0.058 & 0.048 & 0.884 \\
\hline \multicolumn{4}{|c|}{ Karås-Thoresson model $\left(10-22^{\circ} \mathrm{C}\right)$} \\
\hline $1-4$ & 0.024 & 0.082 & 0.894 \\
\hline
\end{tabular}

Estimates of energy density assumed that the relationship between energy density and percent water of somatic tissue, developed by Craig (1977) for Eurasian perch, was appropriate for yellow perch. The Craig (1977) regression appeared to provide realistic estimates of energy density of Saginaw Bay yellow perch for four reasons: (1) estimates of energy density were within the range determined by calorimetry for Saginaw Bay yellow perch (Diana and Salz 1990); (2) energy densities generally increased whenever yellow perch experienced somatic addition during May-October; (3) energy densities generally declined during months when yellow perch did not experience a weight increase; and (4) the technique considered seasonal changes in percent water, which varied even when weight did not. Although the exact relationship between percent water and energy density could differ for yellow perch, this should have had little effect on the age and seasonal trends in energy content because percent water is inversely related to energy content (Niimi and Beamish 1974; Elliott 1976), and yellow perch are a lean species which do not exhibit large seasonal changes in energy density as do species such as alewife (Flath and Diana 1985). Thus, even if the assumption was violated, seasonal patterns should have been similar, and there would have been relatively small errors in monthly point estimates.
We also assumed that lack of growth in age-2 and older yellow perch during late summer was real and assumed no change in weight in calculations of daily ration and as inputs to the energetic models. However, this could have been caused by differential mortality of large individuals, dispersal of larger individuals in each age-class, or sampling error. Back-calculated lengths at age of yellow perch from Saginaw Bay exhibited strong reversed Lee's phenomenon (Salz 1989), which suggested that only the largest individuals of each year-class survived to maturity. This was inconsistent with the hypothesis of higher mortality for large individuals. Emigration of yellow perch from the Wildfowl Bay area was possible, but the trawl catch per unit effort (CPUE) of all age-classes remained high through September (Haas and Schaeffer 1992), suggesting that yellow perch remained in the study area. It is also highly unlikely that a migratory response would have occurred among only the largest individuals of three age-classes. Had the growth cessation been due to sampling error or loss of large individuals, we would have expected to see concurrent decreases in length and weight during those times. This did not occur; with the exception of age- 4 yellow perch collected during October 1988, successive monthly estimates of mean length always increased during MayOctober for all age-classes. Consequently, we conclude that the growth cessation observed during August and September each year was real.

The proportional contribution of individual prey types to total wet weight of the diet was estimated by converting counts of prey items into wet weights using dry-weight data from Hayward and Margraf (1988) and percent water data from a variety of published sources. Differences in prey weights from these estimates could have influenced the proportion that individual prey types contributed to the diet of yellow perch, hence influencing predictions of daily ration by the energetic models. The accuracy of this method was evaluated by reestimating dietary proportions of prey while varying prey weights. Varying dry weights of invertebrate prey by a factor of two never produced more than a $3 \%$ change in the proportion that individual invertebrate prey types contributed to the total wet weight of the diet during a given month for any age-class. This occurred because invertebrates were numerically abundant and suggested that the use of median dry-weight data for invertebrates was appropriate because even potentially large changes in median dry weights had little effect on dietary proportions. 


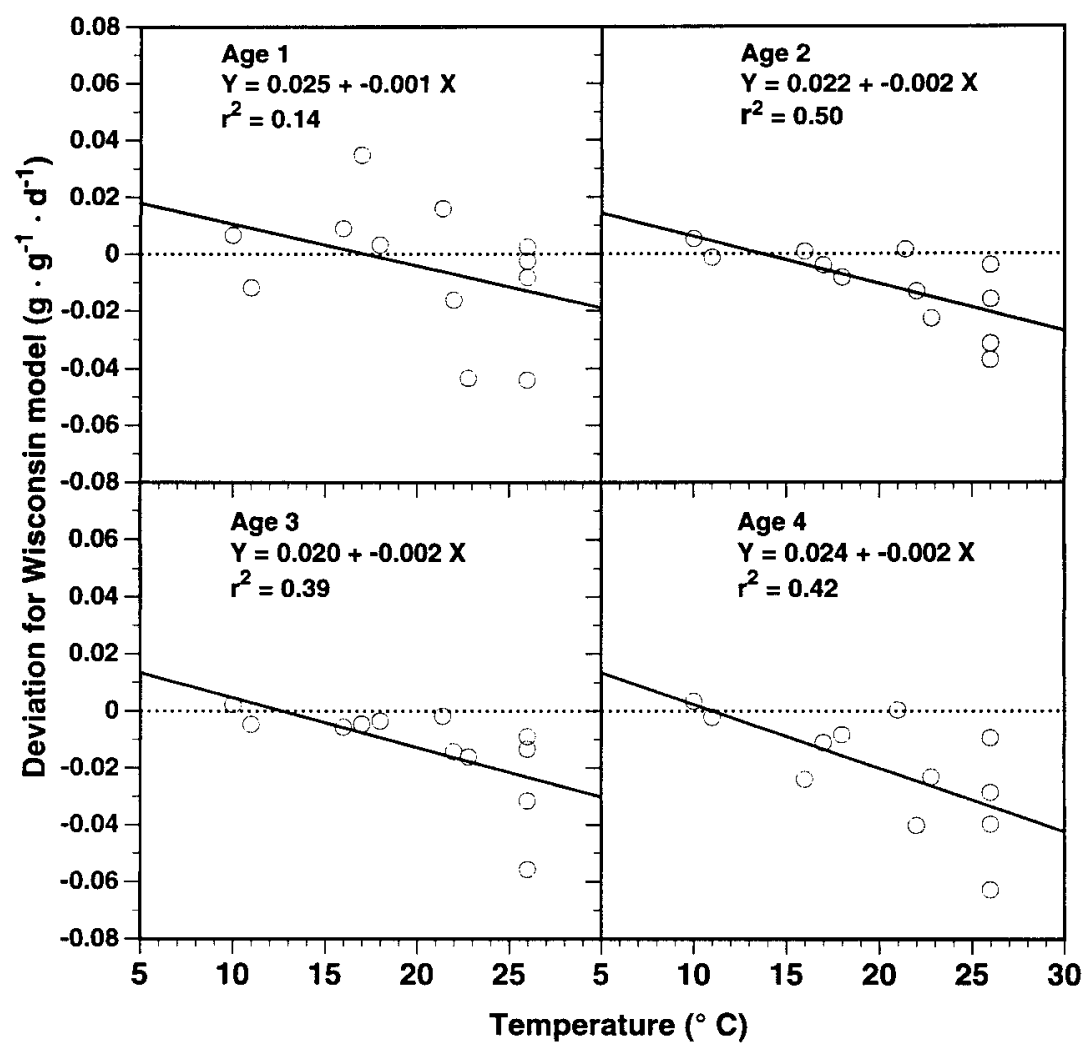

Figure 10.-Deviations between Wisconsin model predictions and field estimates versus temperature $\left({ }^{\circ} \mathrm{C}\right)$. If agreement were perfect (model predictions $=$ field estimates), all data points would fall on the dotted line.

However, varying the median dry weight of prey fish by a factor of two influenced their dietary proportion by up to $15 \%$ during some months because fish were relatively large and rare in diets compared with invertebrates. This suggested that the assumption of $0.1 \mathrm{~g}$ as the median dry weight of an individual prey fish was critical. We evaluated this assumption by reexamining the stomach contents of piscivorous yellow perch. These individuals rarely consumed more than a single forage fish, and their stomachs almost always contained few or no invertebrates. The median wet weight of food from the stomachs of piscivorous yellow perch was $0.406 \mathrm{~g}$, which corresponds closely to the value of $0.40 \mathrm{~g}$ obtained from an estimated dry weight of $0.1 \mathrm{~g}$ for prey fish, and an assumed percent water content of $75 \%$. The value of $0.1 \mathrm{~g}$ as the median dry weight of individual fish prey appears reasonable, and the estimated proportional contribution of individual prey types was close to what would have been observed had prey items been weighed individually.

\section{Potential Errors in Field Estimates of Daily} Ration

We assumed that the gastric evacuation rate developed for Eurasian perch (Persson 1979) was applicable to yellow perch. This assumption was probably not violated at temperatures of $10-22^{\circ} \mathrm{C}$ because the two species have identical temperature optima and preferences (Hokanson 1977), and the Persson (1979) gastric evacuation rate is consistent with yellow perch gut evacuation rates obtained by Boisclair and Leggett (1988) and digestion times for yellow perch observed by Schneider (1973). However, the relationship between $R$ and temperature for Eurasian perch was only estimated for the temperature range of $4-21.7^{\circ} \mathrm{C}$ (Persson 1979). To estimate consumption at higher temperatures, the function had to be extrapolated. During midsummer, temperatures up to $26^{\circ} \mathrm{C}$ were observed at our diel station, and high corresponding values of $R$ from these dates were used to estimate daily ration. If $R$ was overestimated, then daily ration would have been overestimated. 


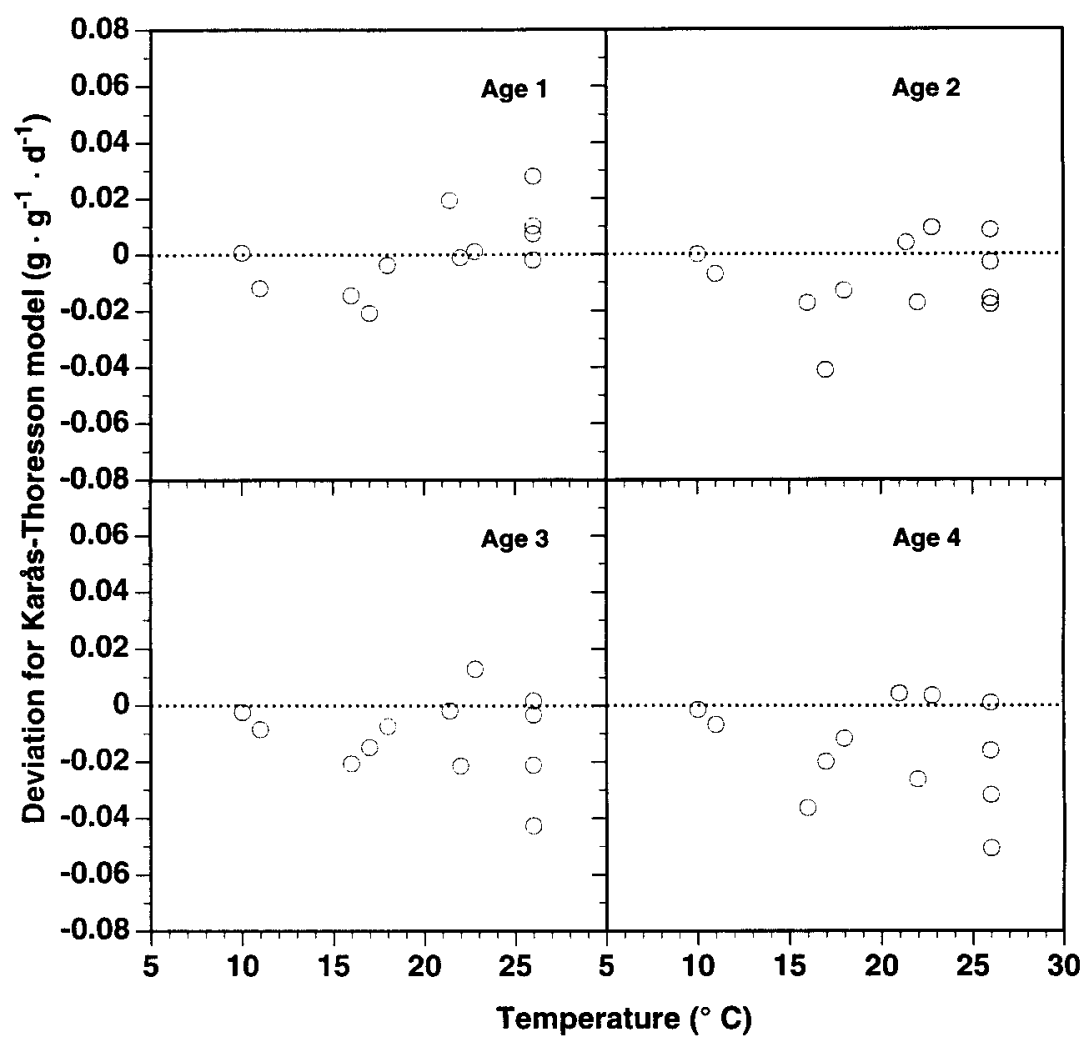

FiguRE 11.-Deviations between $\mathrm{Kara}^{\circ} \mathrm{s}-$ Thoresson model predictions and field estimates versus temperature $\left.{ }^{\circ} \mathrm{C}\right)$. Notion as in Figure 10.

Several lines of evidence suggested that field estimates of daily ration may have been too high at higher temperatures. Virtually all serious disagreements between the models and field data occurred at temperatures where extrapolated values of $R$ were used (Figures 10,11), suggesting that Persson's (1979) equation for Eurasian perch may not be applicable to yellow perch at high temperatures. Boisclair and Leggett (1988) also estimated the relationship between whole-gut evacuation rates $\left(R_{g}\right)$ of yellow perch and temperature. Using their model and allowing for an estimated threefold difference between gastric evacuation and whole-gut evacuation (Boisclair and Leggett 1988), gastric evacuation rates of yellow perch they examined would have been somewhat lower than estimates based on Persson's (1979) data for Eurasian perch, particularly at temperatures above $20^{\circ} \mathrm{C}$. This also suggests that field estimates of daily ration in Saginaw Bay may have been overestimated at high temperatures.

Field estimates of consumption suggested that summer daily ration consistently exceeded about
$6 \%$ body weight per day. Estimates of median daily ration ( 7.0 and $12.0 \%$ body weight per day) consistently exceeded those reported for wild Eurasian perch (Thorpe 1977b) and consistently exceeded field estimates for most other yellow perch populations that exhibited at least some growth (Nakashima and Leggett 1978; Hayward and Margraf 1987; Boisclair and Leggett 1989a). Yellow perch from inner Saginaw Bay are stunted and exhibit energy depletion (Diana and Salz 1990), which appears to result from high population density and food limitation caused by a lack of large benthic prey (Haas and Schaeffer 1992). This is particularly true for age-4 fish, which experience more severe energy depletion than younger age-classes (Salz 1989). Field estimates of daily ration for age4 fish ranged from 0.05 to $0.07 \mathrm{~g} \cdot \mathrm{g}^{-1} \cdot \mathrm{d}^{-1}$ during June-August 1987, and from 0.08 to 0.11 $\mathrm{g} \cdot \mathrm{g}^{-1} \cdot \mathrm{d}^{-1}$ during June-July 1988 , but these yellow perch gained less than $11 \mathrm{~g}$ in body weight during May-September of both years. Metabolic or activity costs may have been high during midsummer (Boisclair and Leggett 1989b), and growth 
TABLE 5.-Energetic model predictions and field estimates of individual cumulative consumption of age-1-4 yellow perch during May-October 1987 and 1988 from the Wildfowl Bay, Saginaw Bay, Lake Huron.

\begin{tabular}{|c|c|c|c|}
\hline \multirow[b]{2}{*}{$\begin{array}{c}\text { Fish age } \\
\text { (years) }\end{array}$} & \multicolumn{2}{|c|}{ Cumulative consumption (g) } & \multirow{2}{*}{$\begin{array}{l}\text { Difference of } \\
\text { model prediction } \\
\text { from field } \\
\text { estimate }(\%)\end{array}$} \\
\hline & $\begin{array}{c}\text { Model } \\
\text { prediction }\end{array}$ & $\begin{array}{l}\text { Field } \\
\text { estimate }\end{array}$ & \\
\hline \multicolumn{4}{|c|}{ Wisconsin model, 1987} \\
\hline 1 & 89.6 & 106.7 & -16.02 \\
\hline 2 & 137.8 & 194.8 & -29.26 \\
\hline 3 & 158.3 & 233.7 & -32.26 \\
\hline 4 & 181.7 & 303.7 & -40.17 \\
\hline \multicolumn{4}{|c|}{ Wisconsin model, 1988} \\
\hline 1 & 97.4 & 128.4 & -24.14 \\
\hline 2 & 142.4 & 194.0 & -26.60 \\
\hline 3 & 156.4 & 246.0 & -36.42 \\
\hline 4 & 181.2 & 330.7 & -45.20 \\
\hline \multicolumn{4}{|c|}{ Karås-Thoresson model, 1987} \\
\hline 1 & 103.8 & 106.7 & -2.71 \\
\hline 2 & 160.6 & 194.8 & -17.55 \\
\hline 3 & 177.9 & 233.7 & -23.87 \\
\hline 4 & 217.3 & 307.7 & -29.37 \\
\hline \multicolumn{4}{|c|}{ Karås-Thoresson model, 1988} \\
\hline 1 & 109.7 & 128.4 & -14.56 \\
\hline 2 & 165.5 & 194.0 & -14.69 \\
\hline 3 & 181.3 & 246.0 & -26.42 \\
\hline 4 & 214.6 & 330.7 & -35.10 \\
\hline
\end{tabular}

may not be well correlated with consumption (Boisclair and Leggett 1989a); however, the slow growth and energy depletion of this population was inconsistent with high daily ration suggested by field estimates. In fact, the only evidence of high consumption by yellow perch in this system was the high point estimates of consumption obtained during June, July, or August.

Piscivory by yellow perch could have also biased estimates of daily ration. The gastric evacuation rate used in field estimates (Persson 1979) was based on experimental meals of small invertebrate prey such as zooplankton, Gammarus spp., and chironomid larvae. Some yellow perch in the sample had consumed fish, which are digested at a slower rate than small invertebrate prey (Durbin et al. 1983), and evacuation rates of prey fish may be linear rather than exponential (Swenson and Smith 1973; Jobling 1986). Had this occurred, daily ration would have been overestimated. To examine the potential bias, piscivorous yellow perch were deleted from the field data, and field estimates were recalculated. Recalculated field estimates of consumption were within $1-2 \%$ of the original data set. Furthermore, lack of agreement between model predictions and field estimates was generally not associated with ages and months having large pro- portions of fish in the stomachs. Consequently, piscivory by yellow perch was probably not an important factor in model-field agreement.

Estimates of cumulative consumption were up to $25 \%$ lower than field estimates for age-1-3 fish. This may not be surprising because even slight differences between model predictions and field estimates can become significant when integrated over the entire growing season. Furthermore, field estimates were derived from a single sample taken about once a month and are influenced strongly by variation in prey availability. Prey availability in Saginaw Bay appeared to vary temporally due to chironomid emergence and pulses of forage fish recruitment (Haas and Schaeffer 1992) and may have influenced this comparison.

\section{Use of The Energetic Models}

Our results suggest that managers should be extremely cautious when estimating consumption rates of yellow perch at high temperatures. Over a temperature range of $10-26^{\circ} \mathrm{C}$, the KaråsThoresson model produced predictions of consumption that were not significantly different from field estimates for age-1-3 fish, while model predictions of consumption of age-4 fish were lower than field estimates. Within the same temperature range, Wisconsin model predictions were lower than field estimates for all age-classes. However, there was considerable evidence that field estimates were too high. Consequently, we were unable to determine whether lack of agreement was the result of improperly defined model parameters (particularly activity), improperly estimated gastric evacuation rates, or some combination of both factors.

Within a reduced temperature range $\left(10-22^{\circ} \mathrm{C}\right)$, agreement between both model predictions and field estimates improved for both models. Predictions generated from the Wisconsin model were not significantly different from field estimates for age-1-3 yellow perch, but model predictions were significantly lower than field estimates for age-4 fish. For the Karås-Thoresson model, there were no significant differences between model predictions and field estimates for any age-class. However, managers should note that yellow perch in Saginaw Bay grew slowly (Diana and Salz 1990). The largest fish we modeled achieved a total length of about $175 \mathrm{~mm}$ and weight of about $45 \mathrm{~g}$. Model performance for larger fish or older yellow perch has not been evaluated.

Both the Wisconsin and Karås-Thoresson models appear to be adequate to address the energetics 
of age-1-3 yellow perch in aquatic systems that do not exceed $22^{\circ} \mathrm{C}$ or in systems where fish have access to (and use) a thermal refuge. The KaråsThoresson model may have some advantage for older or larger fish, and situations where yellow perch experience warm summer temperatures. However, the Karås-Thoresson model may overestimate consumption at high temperatures.

An additional issue regarding the use of energetic models is the difference between absolute and relative comparisons. In this study, we focused on absolute comparisons of model predictions and field estimates of daily ration, and there was uncertainty regarding exactly how much food was consumed by yellow perch. However, using the models provided insight. Both models indicated that the feeding experience of age- 1 and age- 2 fish was extremely different from older fish, and suggested increased food limitation with age. These results were consistent with findings by Diana and Salz (1990) that yellow perch in Saginaw Bay were stunted and with other field data suggesting that stunting was a result of food limitation caused by lack of large benthic invertebrates (Haas and Schaeffer 1992). Thus, predictions from both models were supported strongly by independent field data, other than field estimates of ration.

Future development of energetic models for yellow perch should examine metabolic parameters, gastric evacuation rates, and activity patterns of North American populations across a wide temperature range, particularly for age- 5 and older fish that exceed $80 \mathrm{~g}$. However, field tests of energetic models are clearly not "model versus data" problems but are "model versus model" problems. Uncertainty regarding field estimates of daily ration is an important but overlooked problem, particularly when gastric evacuation rates are considered. Furthermore, we wish to point out that differences in model performance do not represent failures but rather represent refinement. The Wisconsin model was proposed in 1977; the Karås-Thoresson model was developed in 1992 and had the benefit of 15 years of data. The Wisconsin model performed quite well considering the limited data available to its original developers. Model developers and users should expect continual refinement of models and uses as new information becomes available.

Future attempts to corroborate energetic models should consider the laboratory approach used by Whitledge and Hayward (1997) in which fish are fed a known daily ration. This would eliminate uncertainty regarding food intake, growth, and thermal experience of fish. Assumptions about energy density and prey availability could be tested by treatments that vary feeding rates temporally, and there is potential for control of even controversial parameters such as activity. Model inputs could be measured accurately, and errors in prediction should arise solely due to improper parameters, equations, or assumptions within the models. This approach would gain credibility through the use of double-blind experimental designs in which one group of researchers would feed captive fish a known ration, which could be compared with ration predicted by independent researchers using energetic models and having access only to typical model inputs. The issue of whether laboratoryderived physiological parameters can be applied to wild, free-ranging fish remains (Wahl and Stein 1991), but at present there are few if any effective methods for gathering the requisite data. Until better methods are available, studies in small systems such as mesocosms or experimental ponds may provide a way to bridge the gap between laboratory and field studies.

\section{Acknowledgments}

We thank L. Shubel, J. Hodge, K. Koster, J. Clevenger, G. Olsen, L. Hinz, and W. Bryant for dedicated assistance with field sampling and laboratory analyses. A. Sutton assisted with graphs and figures. We are indebted to R. Baker, M. Fabrizio, G. Fowler, R. Salz, and K. Welch for their assistance and advice with energetic models and statistical problems. B. Bjorkelund and G. Arvidsson of the Swedish Office of Science and Technology facilitated communication with G. Thoresson, who kindly clarified model parameters. S. Hewett greatly assisted our work by implementing the Karås-Thoresson model on a personal computer. J. Kitchell and M. Bevelhimer provided valuable comments on an earlier version of the manuscript. This publication is the result of work sponsored by the Michigan Sea Grant College Program, under grant NA-86AA-D-SG043F, project R/GLF-29, from the National Oceanic and Atmospheric Administration, U.S. Department of Commerce, and by funds from the State of Michigan.

\section{References}

Adams, S. M., and J. E. Breck. 1990. Bioenergetics. Pages 389-415 in C. B. Schreck and P. B. Moyle, editors. Methods for fish biology. American Fisheries Society, Bethesda, Maryland.

Bartell, S. M., J. E. Breck, R. H. Gardner, and A. L. 
Brenkert. 1986. Individual parameter perturbation and error analysis of fish bioenergetics models. $\mathrm{Ca}$ nadian Journal of Fisheries and Aquatic Sciences 43:160-168.

Beauchamp, D. A., D. J. Stewart, and G. L. Thomas. 1989. Corroboration of a bioenergetics model for sockeye salmon. Transactions of the American Fisheries Society 118:597-607.

Boisclair, D., and W. C. Leggett. 1988. An in situ experimental evaluation of the Elliott and Persson and the Eggers models for estimating fish daily ration. Canadian Journal of Fisheries and Aquatic Sciences 45:138-145.

Boisclair, D., and W. C. Leggett. 1989a. Among-population variability in fish growth: I. influence of the quantity of food consumed. Canadian Journal of Fisheries and Aquatic Sciences 46:1859-1867.

Boisclair, D., and W. C. Leggett. 1989b. The importance of activity in bioenergetics models applied to actively foraging fishes. Canadian Journal of Fisheries and Aquatic Sciences 46:1859-1867.

Boisclair, D., and W. C. Leggett. 1990. On the relationship between growth and consumption rates: response to comments by R. S. Hayward. Canadian Journal of Fisheries and Aquatic Sciences 47:230233.

Boisclair, D., and W. C. Leggett. 1991. If computers could swim or fish could be programmed: a response to comments by Hewett et al. (1991). Canadian Journal of Fisheries and Aquatic Sciences 48:13371344.

Craig, J. F. 1977. The body composition of adult perch Perca fluviatilis in Lake Windemere, with reference to seasonal changes and reproduction. Journal of Animal Ecology 46:617-632.

Cummins, K. W., and J. C. Wuycheck. 1971. Caloric equivalents for investigations in ecological energetics. International Association of Theoretical and Applied Limnology Proceedings 18:1-151.

Diana, J. S., and R. Salz. 1990. Energy storage, growth, and maturation of yellow perch from different locations in Saginaw Bay, Michigan. Transactions of the American Fisheries Society 119:976-984.

Durbin, E. G., A. G. Durbin, R. W. Langston, and R. E. Bowman. 1983. Stomach contents of silver hake, Merluccius bilinearis, and Atlantic cod, Gadus morhua, and estimation of their daily rations. Fishery Bulletin 81:437-454.

Elliott, J. M. 1976. Body composition of the brown trout Salmo trutta L. in relation to temperature and ration size. Journal of Animal Ecology 45:273-289.

Elliott, J. M., and L. Persson. 1978. The estimation of daily rates of food consumption for fish. Journal of Animal Ecology 47:977-991.

Flath, L. E., and J. S. Diana. 1985. Seasonal energy dynamics of the alewife in southeastern Lake Michigan. Transactions of the American Fisheries Society $114: 328-337$.

Foltz, J. W., and C. R. Norden. 1977. Seasonal changes in food consumption and energy content of smelt in Lake Michigan. Transactions of the American Fisheries Society 106:230-234.
Haas, R. C., and J. S. Schaeffer. 1992. Predator-prey and competitive interactions among walleye, yellow perch, and other forage fishes in Saginaw Bay, Lake Huron. Michigan Department of Natural Resources, Fisheries Research Report 1984, Ann Arbor.

Hartman, K. J., and F. J. Margraf. 1992. Effects of prey and predator abundances on prey consumption and growth of walleyes in western Lake Erie. Transactions of the American Fisheries Society 121:245260.

Hayward, R. S. 1990. Comment on Boisclair and Leggett: can eating really stunt your growth? Canadian Journal of Fisheries and Aquatic Sciences 47:228230.

Hayward, R. S., and F. J. Margraf. 1987. Eutrophication effects on prey size and food available to yellow perch in Lake Erie. Transactions of the American Fisheries Society 116:210-223.

Hayward, R. S., and F. J. Margraf. 1988. Analysis of yellow perch growth in Lake Erie. Ohio Department of Natural Resources, Commercial Fisheries Research and Development Project 3-379-R-1, Study 1, Final Report, Columbus.

Hayward, R. S., F. J. Margraf, C. T. Knight, and D. J. Glomski. 1989. Gear bias in field estimation of the amount of food consumed by fish. Canadian Journal of Fisheries and Aquatic Sciences 46:874-876.

Hewett, S. W., and B. L. Johnson. 1987. A generalized bioenergetics model of fish growth for microcomputers. University of Wisconsin Sea Grant, Technical Report WIS-SG-87-245, Madison.

Hewett, S. W., and B. L. Johnson. 1992. Fish bioenergetics model 2; an upgrade of a generalized bioenergetics model of fish growth for microcomputers. University of Wisconsin, Sea Grant Institute, Technical Report WIS-SG-92-250, Madison.

Hewett, S. W., C. E. Kraft, and B. L. Johnson. 1991. Consumption, growth, and allometry: a comment on Boisclair and Leggett (1989a, 1989b, 1989c, 1989d). Canadian Journal of Fisheries and Aquatic Sciences 48:1334-1357.

Hokanson, K. E. F. 1977. Temperature requirements of some percids and adaptations to the seasonal temperature cycle. Journal of the Fisheries Research Board of Canada 34:1524-1550.

Jobling, M. 1986. Mythical models of gastric emptying and implications for food consumption models. Environmental Biology of Fishes 16:35-50.

Karås, P., and G. Thoresson. 1992. An application of a bioenergetics model to Eurasian perch (Perca fluviatilis L.). Journal of Fish Biology 41:217-230.

Keller, M., J. C. Schneider, L. E. Mrozinski, R. C. Haas, and J. R. Weber. 1987. History, status, and management of fishes in Saginaw Bay, Lake Huron, 1891-1986. Michigan Department of Natural Resources, Fisheries Technical Report 87-2, Ann Arbor.

Kelso, J. R. 1972. Conversion, maintenance, and assimilation for walleye, as affected by size, diet, and temperature. Journal of the Fisheries Research Board of Canada 29:1181-1192.

Kitchell, J. F., and five coauthors. 1974. Model of fish 
biomass dynamics. Transactions of the American Fisheries Society 103:786-798.

Kitchell, J. F., D. J. Stewart, and D. Weininger. 1977. Applications of a bioenergetics model to yellow perch (Perca flavescens) and walleye (Stizostedion vitreum vitreum). Journal of the Fisheries Research Board of Canada 34:1922-1935.

Lessmark, O. 1983. Competition between perch (Perca flavescens) and roach (Rutilis rutilis (L.) in south Swedish Lakes. Doctoral dissertation. University of Lund, Sweden.

Mann, K. M. 1978. Estimating the food consumption of fish in nature. Pages $250-273$ in S. D. Gerking, editor. Ecology of freshwater fish production. Blackwell Scientific Publications, Oxford, UK.

Mills, E. L., and J. L. Forney. 1981. Energetics, food consumption, and growth of young yellow perch in Oneida Lake, New York. Transactions of the American Fisheries Society 41:513-518.

Minton, J. W., and R. B. McLean. 1982. Measurements of growth and consumption of sauger (Stizostedion canadense): implications for fish energetic studies. Canadian Journal of Fisheries and Aquatic Sciences 39:1396-1403.

Nakashima, B. S., and W. C. Leggett. 1978. Daily ration of yellow perch (Perca flavescens) from Lake Memphremagog, Quebec-Vermont, with a comparison of methods for in situ determinations. Journal of the Fisheries Research Board of Canada 35:1597-1603.

Neter, J., W. Wasserman, and M. H. Kutner. 1985. Applied linear statistical models. Erwin, Homewood, Illinois.

Niimi, A. J., and F. W. H. Beamish. 1974. Bioenergetics and growth of largemouth bass Micropterus salmoides in relation to body weight and temperature. Canadian Journal of Zoology 52:447-456.

Persson, L. 1979. The effects of temperature and different food organisms on the rate of gastric evacuation in perch (Perca fluviatilis). Freshwater Biology 9:99-104.

Pierce, R. J., T. E. Wissing, J. G. Jaworski, R. N. Givens, and B. A. Megrey. 1980. Energy storage and utilization patterns of gizzard shad in Acton Lake, Ohio. Transactions of the American Fisheries Society 109:611-616.

Rice, J. A., and P. A. Cochran. 1984. Independent evaluation of a bioenergetics model for largemouth bass. Ecology 65:732-739.

Rottiers, D. V., and R. M. Tucker. 1982. Proximate com- position and caloric content of eight Lake Michigan fishes. U.S. Fish and Wildlife Service Technical Papers 108.

Salz, R. J. 1989. Factors influencing growth and survival of yellow perch from Saginaw Bay, Lake Huron. Michigan Department of Natural Resources, Fisheries Research Report 1964, Ann Arbor.

SAS Institute. 1987. SAS/STAT guide for personal computers, version 6 edition. SAS Institute, Cary, North Carolina.

Schneider, J. C. 1973. Rate of food digestion by yellow perch (Perca flavescens) in relation to size of perch, size and type of food, and temperature. Michigan Department of Natural Resources, Fisheries Research Report 1803, Ann Arbor.

Solomon, D. J., and A. E. Brafield. 1972. The energetics of feeding metabolism, and growth of perch (Perca fluviatilis L.). Journal of Animal Ecology 41:699718.

Swenson, W. A., and L. L. Smith. 1973. Gastric digestion, food consumption, feeding periodicity, and food conversion efficiency in walleye (Stizostedion vitreum). Journal of the Fisheries Research Board of Canada 30:1327-1336.

Theil, H. 1961. Economic forecasting and policy. NorthHolland, Amsterdam, The Netherlands.

Thorpe, J. E. 1977a. Morphology, physiology, behavior, and ecology of Perca fluviatilis L. and Perca flavescens Mitchill. Journal of the Fisheries Research Board of Canada 34:1504-1514.

Thorpe, J. E. 1977b. Daily ration of adult perch, Perca fluviatilis L., during summer in Loch Leven, Scotland. Journal of Fish Biology 11:55-68.

Wahl, D. H., and R. A. Stein. 1991. Food consumption and growth of three esocids: field tests of a bioenergetic model. Transactions of the American Fisheries Society 120:230-246.

Whitledge, G. W., and R. S. Hayward. 1997. Laboratory evaluation of a bioenergetics model for largemouth bass at two temperatures and feeding levels. Transactions of the American Fisheries Society 126: 1030-1035.

Windell, J. T. 1978. Digestion and daily ration in fishes. Pages 151-171 in S. D. Gerking, editor. The biological basis of freshwater fish production. Blackwell Scientific Publications, Oxford, UK.

Wissing, T. E. 1974. Energy transformations by youngof-the-year white bass, Morone chrysops (Rafinesque), in Lake Mendota, Wisconsin. Transactions of the American Fisheries Society 103:32-37. 